\title{
Science Overview Document Indirect and Semi-Direct Aerosol Campaign (ISDAC) April 2008
}
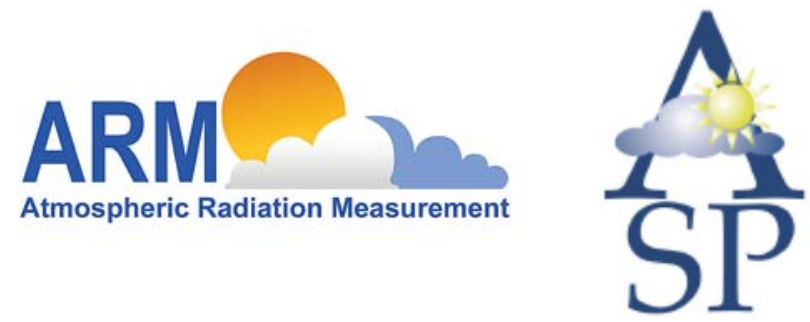

Work supported by the U.S. Department of Energy,

Office of Science, Office of Biological and Environmental Research 


\section{DISCLAIMER}

This report was prepared as an account of work sponsored by the U.S. Government. Neither the United States nor an agency thereof, nor any of their employees, makes any warranty, express or implied, or assumes any legal liability or responsibility for the accuracy, completeness, or usefulness of any information, apparatus, product, or process disclosed, or represents that its use would not infringe privately owned rights. Reference herein to any specific commercial product, process, or service by trade name, trademark, manufacturer, or otherwise, does not necessarily constitute or imply its endorsement, recommendation, or favoring by the U.S. Government or any agency thereof. The views and opinions of authors expressed herein do not necessarily state or reflect those of the U.S. Government or any agency thereof. 


\section{Science Overview Document Indirect and Semi-Direct Aerosol Campaign (ISDAC)) April 2008}

S. Ghan, B. Schmid, J. Hubbe, C. Flynn, A. Laskin, A. Zelenyuk, D. Czizco, and C. Long Pacific Northwest National Laboratory

G. McFarquhar, University of Illinois

J. Verlinde and J. Harrington, The Pennsylvania State University

W. Strapp, P. Liu, A. Korolev, and A. McDonald, Environment Canada

M. Wolde, Canadian National Research Council

A. Fridlind, National Aeronautics and Space Administration, Goddard Institute for Space Studies

T. Garrett and G. Mace, University of Utah

G. Kok, Droplet Measurement Technologies

S. Brooks and D. Collins, Texas A\&M University

D. Lubin, Scripps Institution of Oceanography

P. Lawson, Stratton Park Engineering Company, Inc.

M. Dubey and C. Mazzoleni, Los Alamos National Laboratory

M. Shupe, Cooperative Institute for Research in Environmental Sciences, University of Colorado

S. Xie, Lawrence Livermore National Laboratory

D. Turner, University of Wisconsin

Q. Min, State University of New York - Albany

E. Mlawer, Atmospheric Environmental Research, Inc.

D. Mitchell, Desert Research Institute

Prepared for

the U.S. Department of Energy

under Contract DE-AC05-76RL01830

Pacific Northwest National Laboratory

Richland, Washington 99352 


\begin{abstract}
The ARM Climate Research Facility's (ACRF) Aerial Vehicle Program (AVP) will deploy an intensive cloud and aerosol observing system to the ARM North Slope of Alaska (NSA) locale for a five week Indirect and Semi-Direct Aerosol Campaign (ISDAC) during period 29 March through April 302008. The deployment period is within the International Polar Year, thus contributing to and benefiting from the many ancillary observing systems collecting data synergistically. We will deploy the Canadian National Research Council Convair 580 aircraft to measure temperature, humidity, total particle number, aerosol size distribution, single particle composition, concentrations of cloud condensation nuclei and ice nuclei, optical scattering and absorption, updraft velocity, cloud liquid water and ice contents, cloud droplet and crystal size distributions, cloud particle shape, and cloud extinction. In addition to these aircraft measurements, ISDAC will deploy two instruments at the ARM site in Barrow: a spectroradiometer to retrieve cloud optical depth and effective radius, and a tandem differential mobility analyzer to measure the aerosol size distribution and hygroscopicity.

By using many of the same instruments used during Mixed-Phase Arctic Cloud Experiment (M-PACE), conducted in October 2004, we will be able to contrast the arctic aerosol and cloud properties during the fall and spring transitions. The aerosol measurements can be used in cloud models driven by objectively analyzed boundary conditions to test whether the cloud models can simulate the aerosol influence on the clouds. The influence of aerosol and boundary conditions on the simulated clouds can be separated by running the cloud models with all four combinations of M-PACE and ISDAC aerosol and boundary conditions: M-PACE aerosol and boundary conditions, M-PACE aerosol and ISDAC boundary conditions, ISDAC aerosol and M-PACE boundary conditions, and ISDAC aerosol and boundary conditions. ISDAC and M-PACE boundary conditions are likely to be very different because of the much more extensive ocean water during M-PACE. The uniformity of the surface conditions during ISDAC greatly simplifies the objective analysis (surface fluxes and precipitation are very weak), so that it can largely rely on the European Centre for Medium-Range Weather Forecasts analysis. The aerosol measurements can also be used as input to the cloud models and to evaluate the aerosol retrievals. By running the cloud models with and without solar absorption by the aerosols, we can determine the semidirect effect of the aerosol on the clouds.
\end{abstract}




\section{Contents}

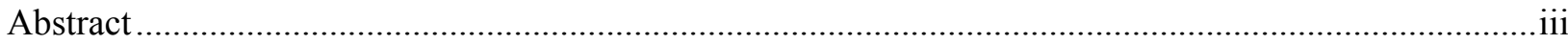

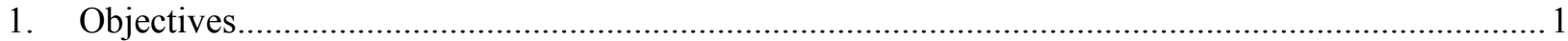

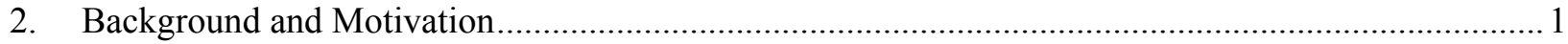

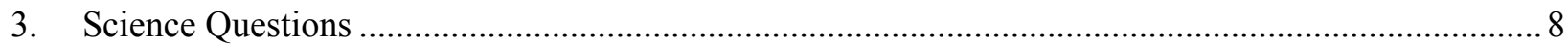

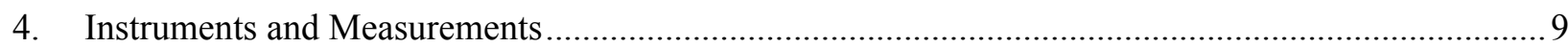

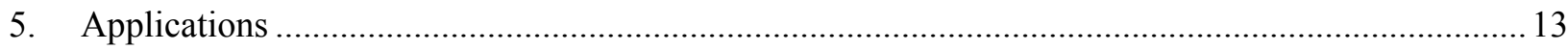

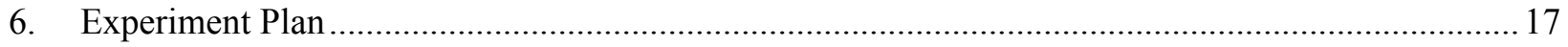

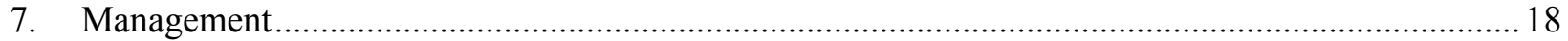

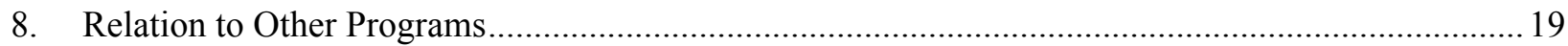

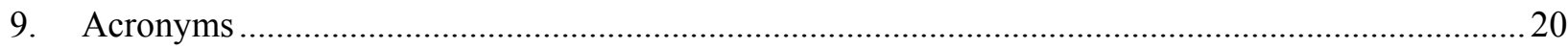

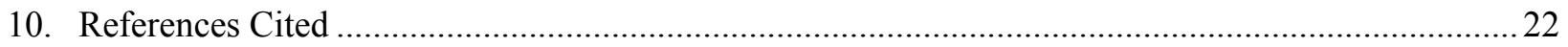

Figures

1. Monthly-average cloud-emissivity $\varepsilon$, cloud coverage A and fraction of time polluted conditions occur derived from ground-based observations at Barrow. .......................................... 2

2. Fractional composition of submicron aerosol mass measured over three years at Barrow ............... 2

3. Cloud frequency from Surface Heat Budget of Arctic Ocean experiment. .................................... 3

4. Ice formation mechanisms in slightly and moderately supercooled clouds. ..................................5

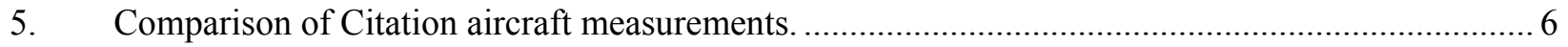

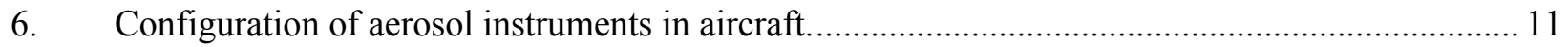

\section{Tables}

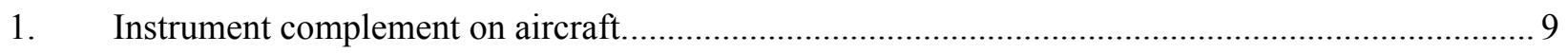

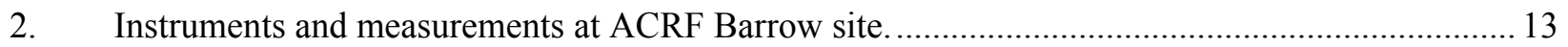

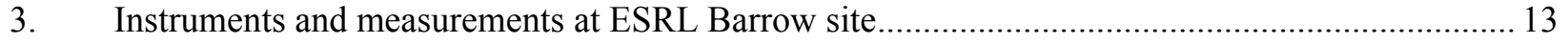

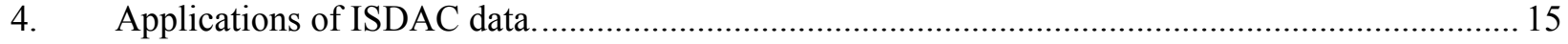

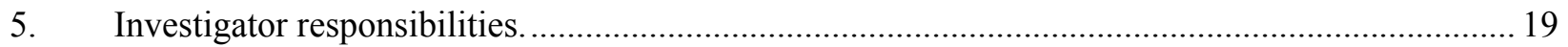




\section{Objectives}

The ISDAC objectives may be summarized in four key questions that have important implications for the treatment of clouds in climate models:

1. How do properties of the arctic aerosol during April differ from those measured during the Mixed-Phase Arctic Cloud Experiment (M-PACE) in October?

2. To what extent do different properties of the arctic aerosol during April produce differences in the microphysical and macrophysical properties of clouds and the surface energy balance?

3. To what extent can cloud models and the cloud parameterizations used in climate models simulate the sensitivity of arctic clouds and the surface energy budget to the differences in aerosol between April and October?

4. How well can long-term surface-based measurements at the ARM Climate Research Facility (ACRF) North Slope of Alaska (NSA) locale provide retrievals of aerosol, cloud, precipitation, and radiative heating in the Arctic?

\section{Background and Motivation}

The ARM Program established a permanent site at the NSA locale for several reasons. (1) Climate models suggest large arctic climate sensitivity due to snow/ice albedo feedback. Snow and sea ice melt each year at the NSA. ARM measurements there could improve understanding of snow and ice albedo feedbacks and how they interact with clouds. (2) The atmosphere at the NSA is colder and drier than at the other sites, thus permitting important tests of radiative transfer codes using surface-based measurements. (3) Of the three permanent ACRF sites, stratiform clouds are most prevalent at the NSA. Stratiform clouds play important roles in cloud feedback. (4) Glaciated and mixed-phase clouds are common at the NSA, so that studies of glaciation are more convenient at the NSA than at the other sites. (5) Aerosols have a strong seasonal cycle at the NSA. This permits studies of both direct and indirect effects of aerosols.

For these reasons many experiments have been conducted at the NSA or elsewhere in the Arctic, and much has been learned from them (Barrie 1986; Curry et al. 1996, 2000; Gultepe et al. 2000; Lawson et al. 2001; McFarquhar et al. 2005; Poellot et al. 2006; Verlinde et al. 2007). Rather than review the full breadth of understanding that has resulted from those experiments, we shall focus on the influence of aerosol on cloud microphysical and optical properties.

Previous studies of arctic aerosol have shown that (a) submicron mass concentrations exceeding $2 \mu \mathrm{g} \mathrm{m}^{-3}$ are often found in stratified layers at altitudes up to $9 \mathrm{~km}$ (Barrie 1986) throughout the Arctic during winter and early spring; (b) this aerosol is predominately anthropogenic and transported from Europe and Asia (Shaw 1982, 1988; Norman et al. 1999); (c) more efficient scavenging during late spring and early summer leads to much lower submicron mass concentrations, particularly within $1 \mathrm{~km}$ of the surface (Wylie and Hudson 2002); and (d) local new particle production from dimethyl sulfide and organic emissions from open ocean water leads to higher number concentrations of ultrafine particles during summer than during winter (Ferek et al. 1995; Leck and Bigg 2005). Figure 1 shows the seasonal cycle of the monthly average cycle of cloud emissivity, cloud coverage, and the fraction of time that polluted conditions occur using four years of ground-based aerosol and radiation observations near Barrow, Alaska. There is a marked transition between March and May: clouds become more common and thicker while pollution events become increasingly rare (Garrett and Zhao 2006). It is this transition that may be 
most relevant for setting the timing of ISDAC. Figure 2 shows the submicron aerosol is primarily composed of sea salt and sulfate during winter, but with a large fraction of unknown residual mass during summer. Measurements of aerosol absorption (Hansen et al. 1989, 1997a) at Barrow suggest at least some of the residual mass is black carbon. Single-particle analysis of 0.2-2 $\mu \mathrm{m}$ particles sampled from aircraft during March above Svalbard, Norway, in the North Atlantic (Hara et al. 2003) suggests that under the most polluted conditions the arctic aerosol are predominantly composed of external mixtures of black carbon and sulfate, with internal mixing more common for background conditions. Sea salt is present only near the surface as externally-mixed particles, and mineral dust is a significant but not major fraction at times. Single-particle composition has rarely been determined at the NSA, even at the surface.

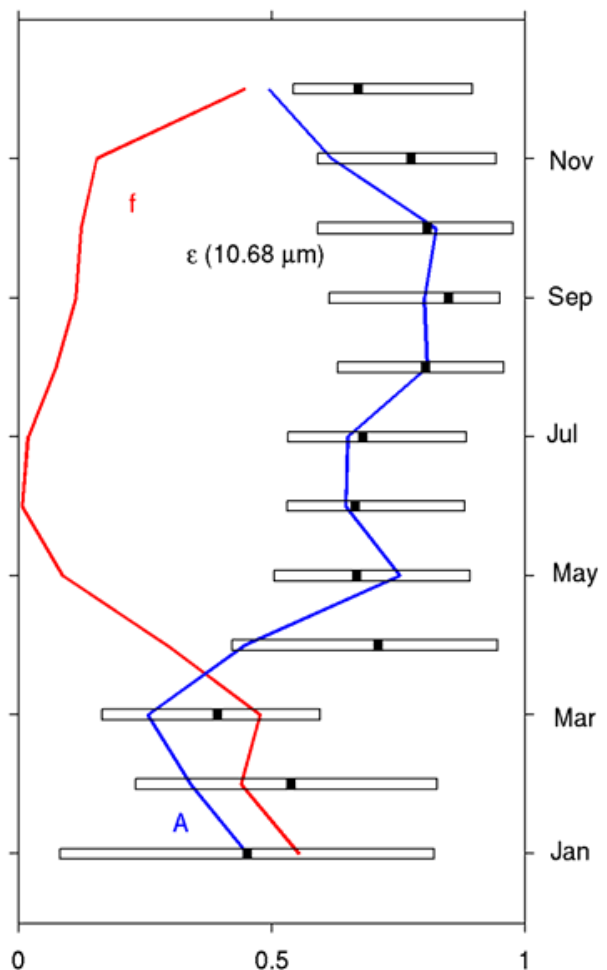

Figure 1: Monthly-average cloud-emissivity $\varepsilon$ (shown as quartile plot), cloud coverage $A$ (blue) and fraction of time polluted conditions occur (red) derived from ground-based observations at Barrow (details in Garrett and Zhao 2006).

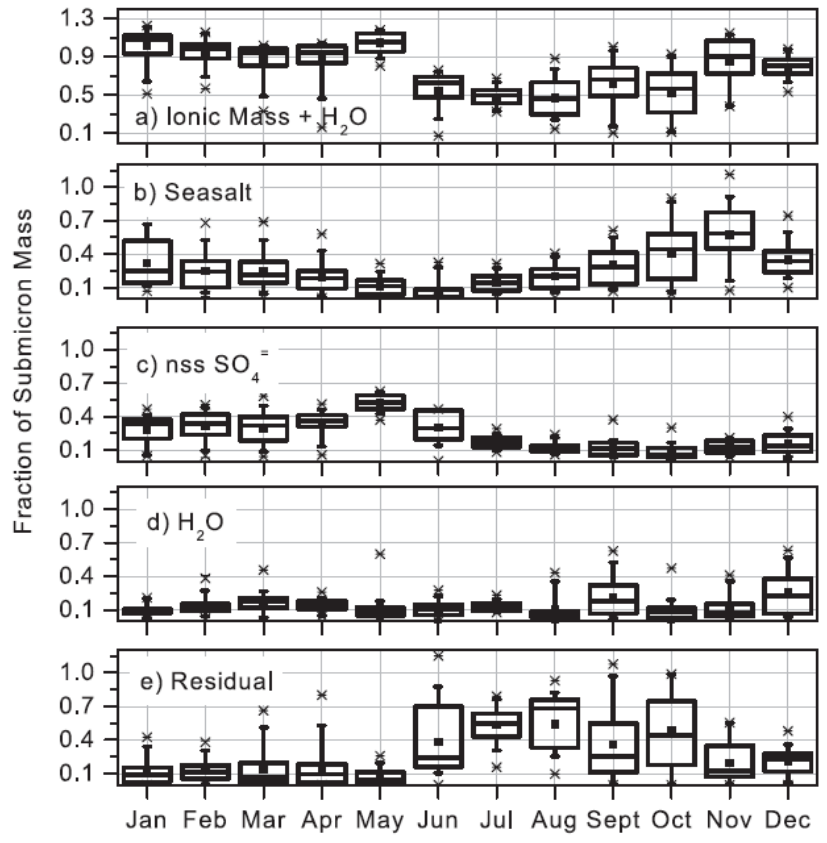

Figure 2: Fractional composition of submicron aerosol mass measured over three years at Barrow. From Quinn et al. (2002).

Arctic cloud condensation nuclei $(\mathrm{CCN})$ measurements suggest considerable variability. Yum and Hudson (2001) found CCN concentrations at a supersaturation of 1\% during May 1998 that were a factor of four greater than those found by Hegg et al. (1995, 1996) during both April 1992 and June 1995. Variability between days was a factor of two. Measurements near Iglooik, Northwest Territories, Canada, in February 1982, indicate CCN concentrations of $\sim 80 \mathrm{~cm}^{-3}$ for stratiform clouds in polluted air, compared to $\sim 30 \mathrm{~cm}^{-3}$ in cleaner air (Leaitch et al. 1984). Thus, CCN measurements for any given day are not necessarily representative of conditions for another day. On the basis of differences in measured aerosol concentrations, one might expect to find higher arctic $\mathrm{CCN}$ concentrations during winter and early spring than during summer and early autumn, but field measurements have yet to confirm this expectation. 
Measurements of ice nuclei (IN) concentration in the Arctic (Borys 1989) suggest lower IN concentrations relative to total aerosol number for polluted conditions than for remote unpolluted conditions, which may explain the persistence of the arctic liquid cloud water. Rogers et al. (2001) found small ( $<0.16$ per liter) IN concentrations most of the time during May 1998, with values exceeding 4 per liter occurring $40 \%$ of the time and IN concentrations exceeding $0.1 \%$ of total aerosol number $20 \%$ of the time. Variability spanned five orders of magnitude. Single particle analysis of ice crystal residuals indicated IN composed of silicate and carbon. Mean IN concentrations measured during the ARM M-PACE in October 2004 (Prenni et al. 2007) are a factor of 5-10 lower than those measured during May 1998 by Rogers et al. (2001), mainly because of more periods during M-PACE with small concentrations of IN.

Surface-based retrievals of cloud type for one year near the NSA (Shupe et al. 2005, 2006) suggest the presence of both supercooled droplets and ice crystals at any time of year (Figure 3). Liquid-only clouds are much more common during the summer months, occurring $40 \%$ of the time compared with less that $10 \%$ during winter months. Drizzle occurs only during April-September. Ice-only clouds occur about $40 \%$ of the time throughout the year, and mixed-phase clouds are common throughout the year. Multilayer clouds are common, and mixed-phase and all liquid clouds often persist for days. Liquid water paths are generally greatest during August and September, when open ocean water is greatest, and are about half as great during April (Shupe et al. 2006), when open ocean water is minimal.

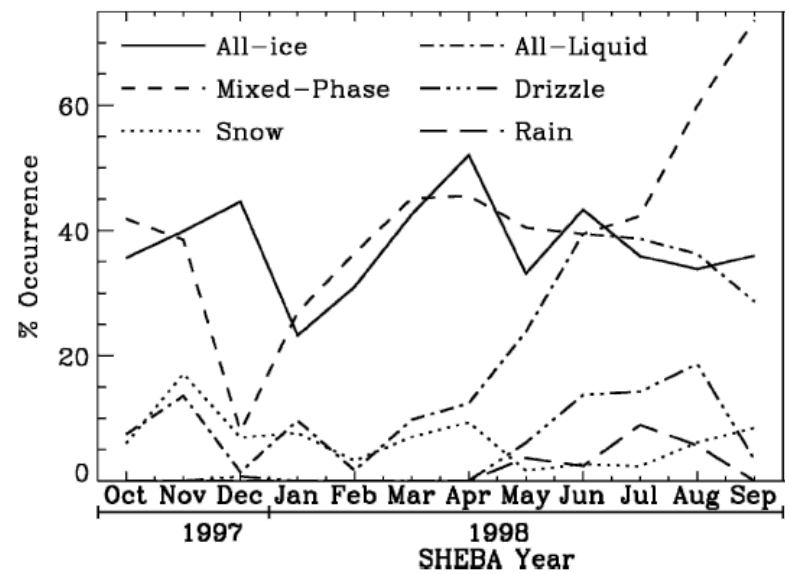

Figure 3: Cloud frequency from Surface Heat Budget of Arctic Ocean (SHEBA) experiment (Shupe et al. 2005).

A few in situ aircraft studies have related the measured aerosol to measured droplet number in the Arctic. Hegg et al. (1996) found that CCN concentration at 1\% supersaturation explained $66 \%$ of the variability of droplet number concentration. Garrett et al. (2002) found evidence of aerosol influence on droplet number and drizzle on a flight in June 1998. Peng et al. (2002) found higher droplet number concentrations for higher accumulation mode aerosol number concentrations in arctic clouds. These conclusions are consistent with many studies of stratiform clouds in midlatitudes (Gultepe and Isaac 1996; Peng et al. 2002; Meskhidze et al. 2005). In situ measurements during the ARM M-PACE in October 2004 found droplet number concentrations of $50-100 \mathrm{~cm}^{-3}$ significantly lower than the $50-350 \mathrm{~cm}^{-3}$ concentrations measured during the First ISCCP Regional Experiment-Aerosol Characterization Experiment (FIRE-ACE) in April 1998 (Peng et al. 2002). This contrast between seasons presents an opportunity to use the ACRF NSA locale to study the aerosol indirect effect. 
Although the sunlight available to produce an indirect effect at visible wavelengths is quite small in the Arctic except during the summer when much of the anthropogenic aerosol has been scavenged, recent work (Garrett et al. 2002, 2004; Garrett and Zhao 2006; Lubin and Vogelmann 2006) has suggested a significant longwave indirect effect of aerosol, in which higher droplet numbers and smaller droplet sizes increase the longwave emissivity of clouds. The radiative forcing by this mechanism has been estimated to be several $\mathrm{Wm}^{-2}$, but the uncertainty is high because no reliable proxy long-term measures of CCN are available in the Arctic. Previous studies relied on surface measurements of either total particle number (which is often dominated by particles too small to nucleate droplets) or visible extinction (which is often dominated by particles that contribute little to the total CCN concentration). The addition of a CCN instrument at the NSA in 2006 is an important step toward addressing this measurement limitation, but aircraft measurements are needed to assess how representative the surface measurements are of CCN concentrations aloft, or how well retrievals using lidar backscatter and surface CCN measurements (Ghan et al. 2006) can improve upon the surface CCN measurements.

Field studies have also shown that the low IN concentrations observed in the Arctic often yield low crystal number concentrations. Rogers et al. (2001) found that for thin stratus clouds at temperatures between $-15^{\circ}$ and $-20^{\circ} \mathrm{C}$, crystal number concentrations were low (1 per liter), and supercooled water persisted for several days. However, it appears that at least one of several other crystal production processes is needed to explain measured ice crystal number concentrations well in excess of measured IN concentrations found in many arctic clouds at temperatures between $-5^{\circ}$ and $-20^{\circ} \mathrm{C}$ (Hobbs and Rangno 1998; Rangno and Hobbs 2001), as illustrated in Figure 4. Even if IN concentrations were the same in all seasons, one might expect seasonal variations in crystal number due to seasonal variations in temperature and aerosol-induced changes in droplet number and droplet size. Based on aircraft observations, Rangno and Hobbs (2001) hypothesized that for slightly supercooled conditions $\left(-5^{\circ}\right.$ to $\left.-10^{\circ} \mathrm{C}\right)$, low droplet number concentrations and hence large droplets can produce drizzle and crystal production by riming/splintering. For moderately supercooled conditions $\left(-10^{\circ}\right.$ to $\left.-20^{\circ} \mathrm{C}\right)$, they hypothesized that low droplet numbers and hence large droplets can produce crystals by freezing and shattering or by colliding with and fragmenting crystals. These mechanisms could greatly accelerate the glaciation of and precipitation from arctic clouds, but we have no clear proof that they are in fact sufficient to explain the observations. Furthermore, although temperature may explain much of the observed seasonal variability in the frequency of liquid-only arctic clouds illustrated in Figure 3, the dependence of these ice production mechanisms on droplet size is sufficient to suggest a significant role for aerosol-induced droplet nucleation as well. Data collected during ISDAC will permit investigations of relationships between IN and ice crystal number given the state-of-the-art suite of aerosol and cloud microphysics instruments proposed.

The expected contrast between the April and October aerosol conditions at the NSA presents an ideal opportunity to test our understanding of droplet nucleation, crystal nucleation and ice multiplication mechanisms both through analysis of the aerosol, liquid and ice measurements to be collected and by evaluating the ability of cloud models to simulate differences between the clouds during the two seasons. Although conditions were unseasonably warm during the October 2004 M-PACE, persistent multi-phase boundary clouds blanketed the NSA region throughout October 8-12. Cloud-top temperatures dropped as low as $-17^{\circ} \mathrm{C}$ during this period, and in situ observations from the Citation aircraft indicated ice water path (IWP)/liquid water path (LWP) values as high as 10-20\% along with drop concentrations typically in the range of 50-100 $\mathrm{cm}^{-3}$. These conditions, representative of 'Type $V^{\prime}$ in Figure 4, would contrast sharply with the 'Type IV' conditions expected in April. Thus, studies of the relationships between 


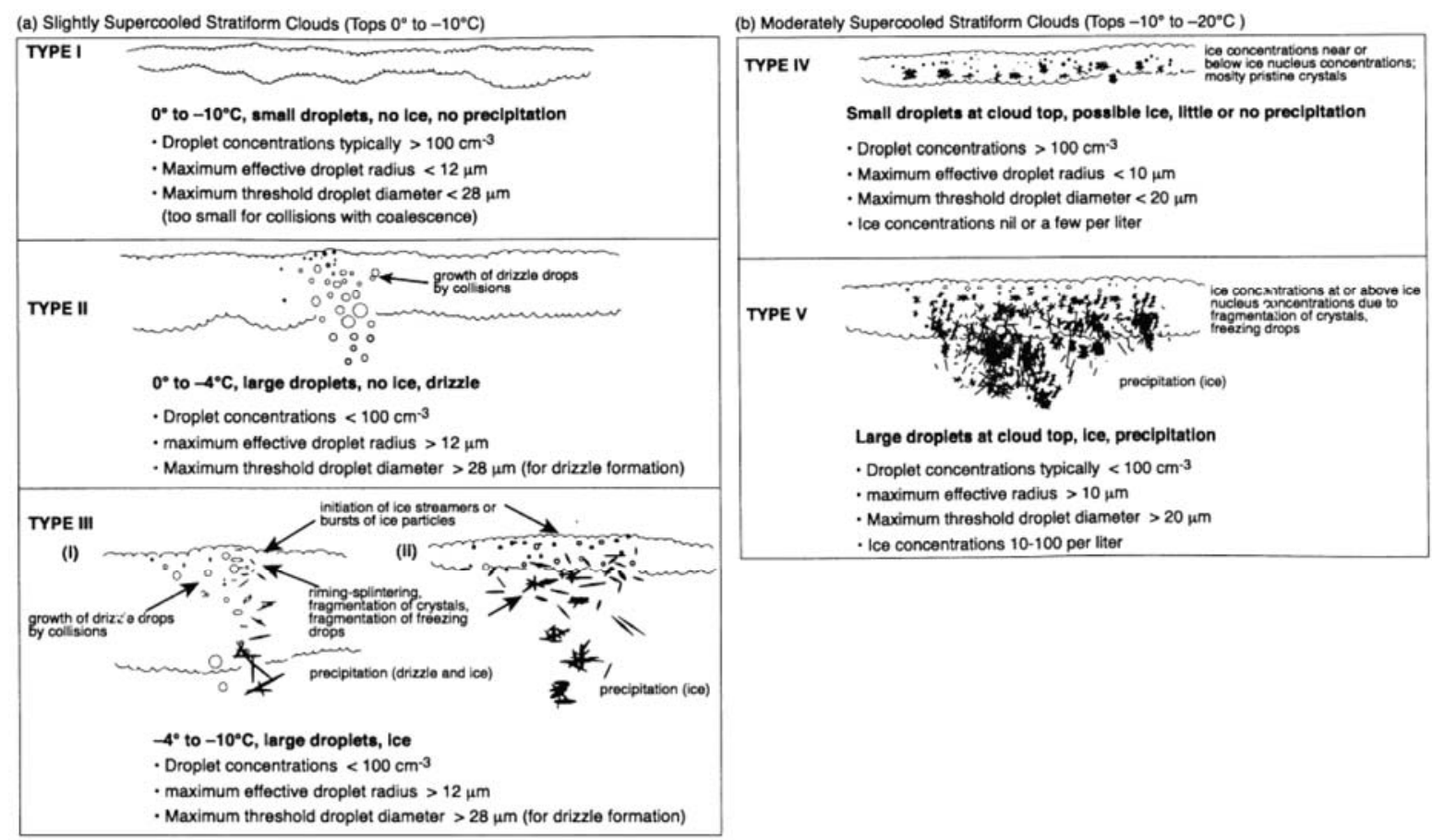

Figure 4: Ice formation mechanisms in slightly (a) and moderately (b) supercooled clouds (Rangno and Hobbs 2001).

aerosols and cloud microphysical properties from the ISDAC data will offer considerable insight into nucleation and ice multiplication mechanisms that cannot be obtained from the M-PACE data alone.

April is ideal to conduct ISDAC for many reasons. First, April represents a transition between clean and polluted conditions with different studies reporting variations in the seasonal cycle of pollution (e.g., Quinn et al. 2002; Garrett and Zhao 2006). This might be related to varying influences of meteorology for different years, differences between the surface and cloud layers and the fact that varying observation techniques emphasize contributions of varying particle sizes in defining pollution. Regardless, observations during April are preferable to those in March for ISDAC goals defined below because there is more sunlight, greater variability in aerosol/polluted conditions, and because April observations will allow an investigation into the competition between pollution and scavenging.

The ARM Cloud Modeling Working Group recently developed a modeling case study (M-PACE "Case B") based primarily on Flight $9 \mathrm{~b}$ over October 9-10, representative of the stratus conditions encountered. Here, we briefly summarize preliminary findings from comparison of large-eddy simulations of Case B, using size-resolved microphysics with prognostic IN (Fridlind et al. 2007), with the observations (McFarquhar et al. 2007), which ultimately motivate additional study of stratus clouds under contrasting springtime conditions. When initializing with the Case B specifications, including subsidence and advective forcings, it was found that the small number of IN observed ( $0.2 / \mathrm{L}$ on average) produces, not surprisingly, very little ice compared with observations (Figure 5). Furthermore, processes 


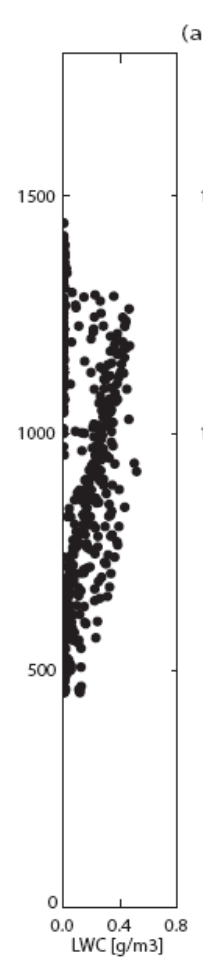

(a) DATA: Flight $9 \mathrm{~b}$
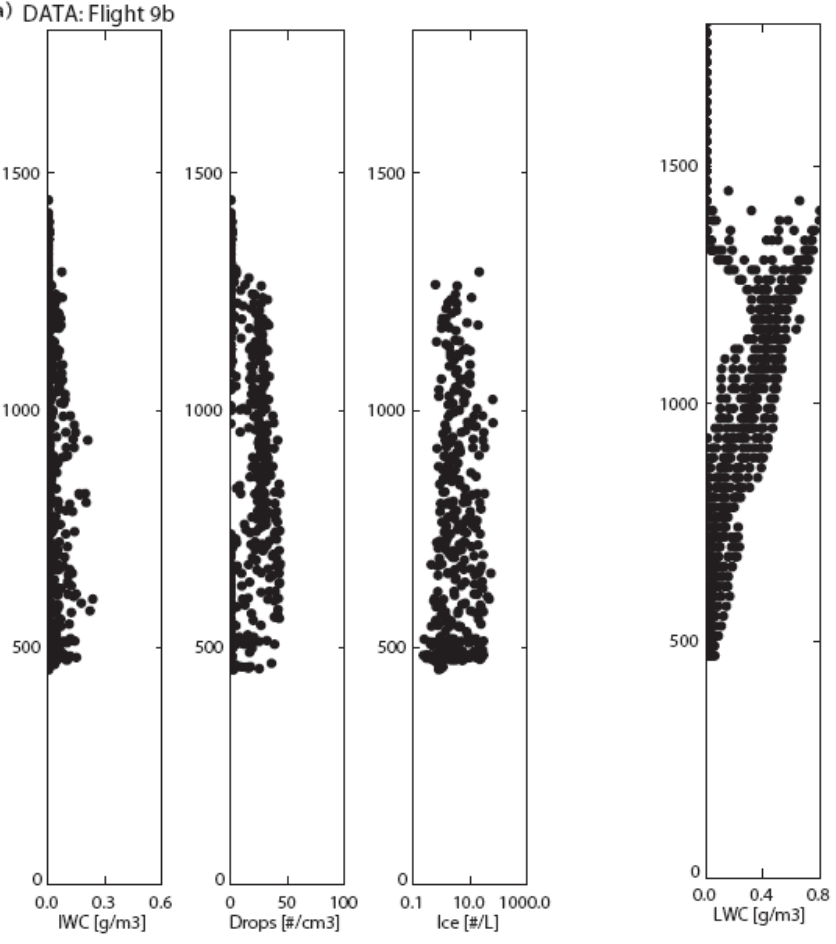

(b) MODEL: $0.2 / L$ IN
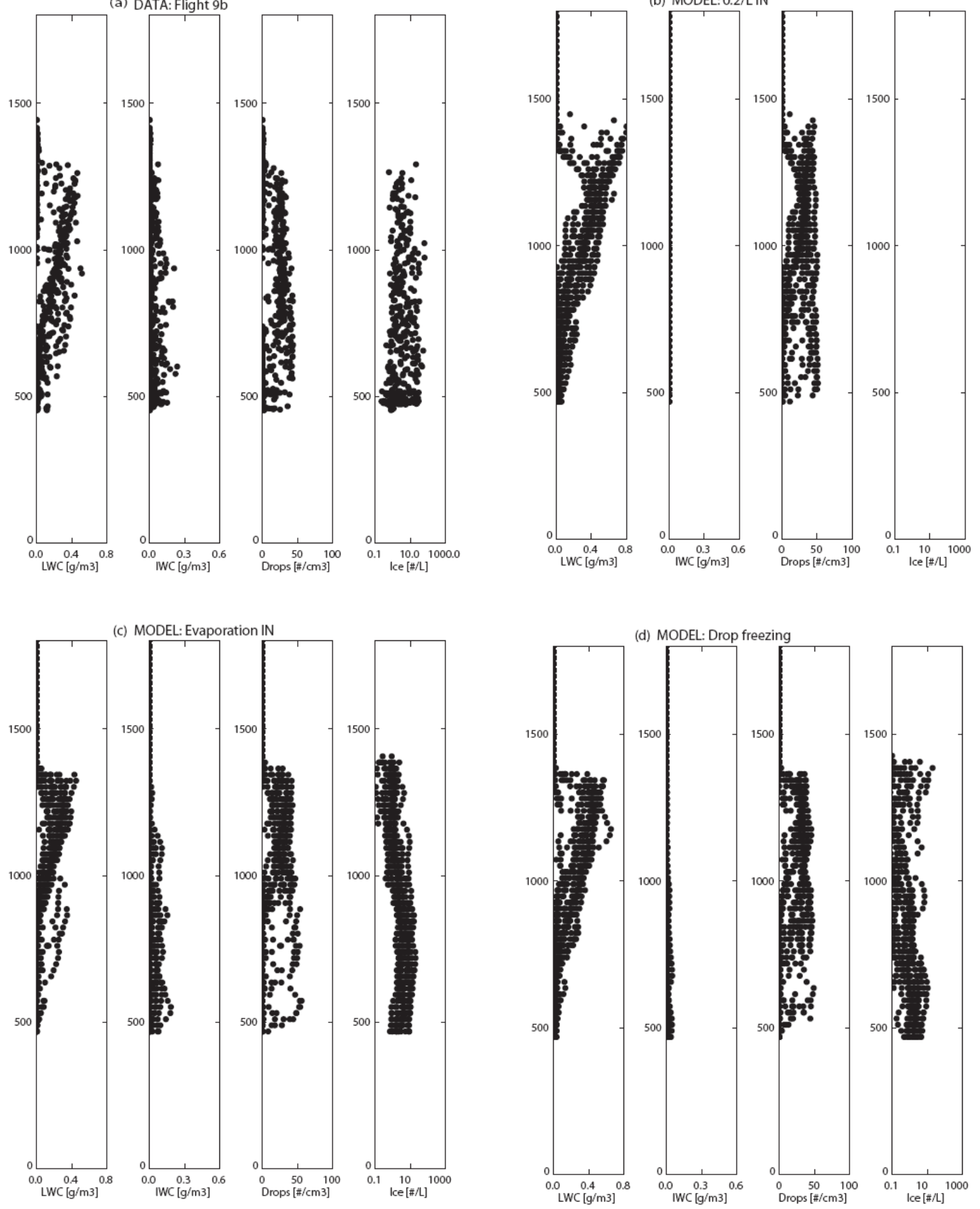

(d) MODEL: Drop freezing

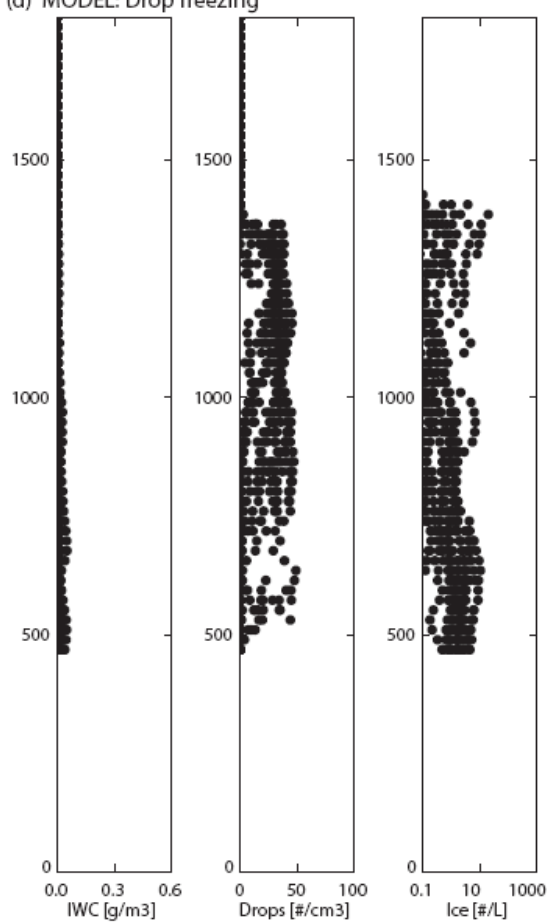

Figure 5: Comparison of Citation aircraft measurements, as a function of elevation in meters (a) with simulation results, for the case of ice formation via observed IN (b), in addition to the production of nuclei from drop evaporation residues (c) or the freezing of drops during the evaporation process (d). Measurements reported in McFarquhar et al. (2007). Model results reported in Fridlind et al. (2007). 
proposed by Rangno and Hobbs (2001) to account for additional crystals (freezing drops and crystal fragmentation) had little impact. Two other possible ice production mechanisms in the literature were tested. When drop evaporation residues are considered to produce IN at the rate of $1 \mathrm{IN}$ per 100,000 drops evaporated (Rosinski and Morgan 1991) or droplets spontaneously freeze during the final stages of evaporation (Cotton and Field 2002), predicted ice concentrations in terms of both number and mass more closely resemble the observations. Work is under way to attempt to distinguish if either of these mechanisms is likely, by comparing modeled size distributions with observations in more detail. Many questions remain about the behavior of IN in the field, such as preactivation processes that are not preserved by the continuous flow diffusion chamber (CFDC) instrument. However, these preliminary modeling results from the M-PACE Intensive Operational Period (IOP) indicate that obtaining a set of observations similar to M-PACE but under the contrasting case of high droplet number concentrations could elucidate the mechanisms of ice formation that affect not only arctic clouds but also many other supercooled cloud types (e.g., Beard 1992).

A critical current issue in cloud physics is to understand the concentrations of small (maximum dimension $\mathrm{D}<60 \mu \mathrm{m}$ ) ice crystals in glaciated ice clouds and mixed phase clouds. In situ measurements reported in Lawson et al. (2001) for arctic clouds, Ivanova et al. (2001) and Lawson et al. (2006) for synoptic (midlatitude) cirrus clouds, and Korolev et al. (2003) for frontal clouds indicate typical ice crystal concentrations ranging from about 0.5 to $5.0 \mathrm{~cm}^{-3}$ without significant temperature dependence. Except for homogeneous freezing nucleation at temperatures less than $-34{ }^{\circ} \mathrm{C}$, existing theories of ice nucleation do not easily account for such concentrations. Measurements of ice particle size distributions (SD) indicate that the high concentrations are associated with small ice crystals. The instruments measuring these small ice crystal concentrations have inlets where incoming large ice particles $(\mathrm{D}>350 \mu \mathrm{m})$ may shatter, producing many small ice fragments. Thus the high ice crystal concentrations may be artifacts from shattering at the probe inlet. Recent GCM simulations (Mitchell et al. 2006) have shown that GCM predictions can be very sensitive to the representation of the SD small mode ( $<60 \mu \mathrm{m})$ in cirrus clouds. This is largely due to changes in ice sedimentation rates which affects the lifetime and ice content of clouds. Therefore it is important, if possible, for ISDAC research to provide guidance to climate modelers on small ice crystal concentrations in arctic clouds.

The presence of absorbing material in the aerosol suggests the possibility of a semi-direct effect, in which absorption of sunlight heats the aerosol layer and inhibits cloud formation (Hansen et al. 1997b). This mechanism has been previously explored at low latitudes (Ackerman et al. 2000; Koren et al. 2004). Whether the semi-direct effect plays a significant role in the Arctic depends on how long the absorbing aerosol remains in the arctic atmosphere as the sun rises during the spring. If the aerosol is scavenged by precipitation before the sun rises, the semi-direct effect will be negligible. However, if it persists into late spring it can absorb considerable sunlight and affect the relative humidity both through warming of the layer and by stabilizing the troposphere, reducing the turbulent transport of water vapor from the surface. Measurements of aerosol absorption in arctic clouds could be used in model simulations to address this issue.

The distinguishing signature of ARM is its set of long-term surface-based retrievals. This set includes retrievals of aerosol extinction (Welton et al. 2000, 2002; Schmid et al. 2006), CCN concentration (Ghan and Collins 2004; Ghan et al. 2006), cloud base and cloud top (Clothiaux et al. 2000), LWP (Westwater et al. 2001), liquid water content (LWC), droplet effective radius, and droplet number (Frisch et al. 1995), water path, optical depth, and effective radius (column integrated) of the ice and water components of mixed-phase clouds (Min and Harrison, 1996; Min et al, 2004; Turner 2005), and ice water content (IWC) 
(Matrosov 1999; Matrosov et al. 2002; Wang et al. 2004; Shupe et al. 2005). Atmospheric Emitted Radiance Interferometer (AERI) data from NSA and Kuparuk, combined with lidar and radiosonde measurements, also provide qualitative estimates of ice crystal concentrations for $\mathrm{D}<70 \mu \mathrm{m}$ (DeSlover et al. 1999; Mitchell et al. 2003, 2006), retrievals of effective particle size, LWP, IWP, and optical depth (Mitchell et al. 2006). From all these retrievals, vertical profiles of radiative heating are being derived. Retrievals are essential for evaluating cloud and radiative transfer models designed for climate models, and they have been used to isolate the aerosol influence on clouds.

\section{Science Questions}

These considerations lead to the following primary and secondary questions that, if answered, would provide a solid foundation for parameterizations of arctic clouds in climate models.

How do properties of the Arctic aerosol during spring transition differ from those measured during

$1 \quad M-P A C E$ in fall transition?

1A Are $\mathrm{CCN}$ and IN concentration in the Arctic higher during spring transition than in the fall transition?

1B What are the physical and chemical properties, including degree of internal mixing, of the arctic aerosol during April?

1C How do the vertical distributions of the aerosol during April differ from those during October?

2 To what extent do the different properties of the arctic aerosol during April produce differences in clouds?

2A Do the more polluted conditions during April in the Arctic enhance droplet number, crystal number, droplet dispersion, cloud optical depth, and longwave emissivity? How do these cloud properties depend on the degree of pollution?

2B How do numbers of arctic IN vary as function of temperature and supersaturation, and how does this compare against parameterizations used in models?

2C Does glaciation enhancement by increased IN dominate glaciation suppression by droplet size reduction associated with increased CCN?

2D What is the relationship between IN and ice crystal number and what role does ice multiplication play in determining ice crystal number concentration?

2E What are the spatial and temporal scales over which water and ice mix in mixed-phase clouds, and how does this depend on aerosol concentrations?

2F How do differences in large-scale meteorological forcing and surface conditions affect how cloud properties differ in the polluted April compared with October?

$2 \mathrm{G}$ What role do aerosols play in explaining why springtime clouds observed during SHEBA persist so long, even though surface fluxes were weak and the ice precipitated?

$2 \mathrm{H} \quad$ What role does aerosol absorption of sunlight play in the dissipation of springtime arctic clouds?

2I Which processes contribute to the scavenging of arctic aerosol during spring?

3 To what extent can cloud models and the cloud parameterizations used in climate models simulate the sensitivity of arctic clouds to the differences in aerosol between the arctic spring and fall transitions?

3A Can cloud models and parameterizations simulate the seasonal differences in the droplet number, crystal number, glaciation, riming, droplet dispersion, cloud optical depth, and longwave emissivity in the Arctic?

3B Can models and parameterizations successfully simulate the partitioning of cloud water and cloud ice in arctic clouds and the longevity of spring transition arctic clouds?

4. How well can long-term surface-based measurements at the ACRF NSA locale provide retrievals of aerosol, cloud, precipitation, and radiative heating in the Arctic?

4A How does the performance of these retrievals depend on stratification, cloud thickness, and cloud phase? 


\section{Instruments and Measurements}

The Canadian NRC Convair 580 was selected as the intensive cloud and aerosol observing system for the ACRF NSA ISDAC project. This aircraft deploys a large array of measurement systems that together provide high temporal resolution measurements of temperature, humidity, total particle number, aerosol size distribution, CCN concentration, IN concentration, optical scattering and absorption, vertical velocity, cloud liquid water and ice contents, cloud droplet and crystal size distributions, cloud particle shape, and cloud extinction. Moreover, the aircraft measurement systems include a suite of advanced cloud radars that can provide contextual information for the in situ measurements.

The minimum set of instruments for providing observations has been identified based on experience obtained during M-PACE (e.g., McFarquhar et al. 2005; Poellot et al. 2006; Verlinde et al. 2006) and other projects (e.g., Korolev et al. 1999; Hobbs and Rangno 1998; Gultepe et al. 2000; Cober et al. 2001; Lawson et al. 2001). Several additions to the M-PACE instruments are needed for evaluating cloud models and for closure studies of aerosols and cloud droplet number, and IN and ice crystal number. In particular, improved observations of humidity, vertical velocity and aerosol/ice nuclei numbers and compositions are needed to address the ISDAC science questions. In addition, we need faster time response measurements of the liquid-ice interface than was available during M-PACE and improved estimates of the IWC in mixed-phase clouds. The instruments to be deployed on the aircraft and the variables they measure are listed in Table 1 (acronyms in Appendix). Each instrument has a critical role. As shown by Klein et al. (2006), a subset of these instruments was used to derive cloud properties currently being used to compare model simulations and observations of M-PACE clouds.

Table 1: Instrument complement on aircraft.

\begin{tabular}{|c|c|}
\hline Instrument & Measurements \\
\hline \multicolumn{2}{|r|}{ Atmospheric State } \\
\hline 3 Rosemont 102 probes & Temperature \\
\hline NCAR reverse flow probe & Temperature \\
\hline EG7G chilled mirror hygrometer & Humidity \\
\hline LICOR LIC2G2 & Water vapor and $\mathrm{CO}_{2}$ mixing ratio \\
\hline Rosemount 858 gust probe & Vertical velocity \\
\hline \multicolumn{2}{|c|}{ Liquid/Super-cooled Liquid } \\
\hline Rosemount icing (RICE) probe & Detects supercooled liquid \\
\hline Vibrameter & Detects supercooled liquid \\
\hline Nevzorov LWC/TWC probe & Liquid and total condensed water concentration \\
\hline CSIRO King probe & Liquid water concentration \\
\hline \multicolumn{2}{|r|}{ Cloud Microphysics } \\
\hline DMT Cloud Spectrometer and Imager & Total water concentration \\
\hline $\begin{array}{l}\text { DMT Cloud, Aerosol and Precipitation } \\
\text { Spectrometer }\end{array}$ & $\begin{array}{l}\text { Temperature, liquid water and droplet number conc., cloud } \\
\text { particle size distribution }(0.5-1500 \mu \mathrm{m})\end{array}$ \\
\hline SPEC Cloud Particle Imager & Cloud particle images $(15-2500 \mu \mathrm{m})$ \\
\hline PMS FSSP-100X & Small particle spectrum $(3-45 \mu \mathrm{m})$ \\
\hline PMS 2D2C & Imaging cloud particles $(25-800 \mu \mathrm{m})$ \\
\hline SPEC 2DS & Cloud particle size distribution $(50-1000 \mu \mathrm{m})$ \\
\hline PMS 2DP & Imaging cloud particles $(200-6400 \mu \mathrm{m})$ \\
\hline
\end{tabular}


Table 1: (contd.)

\begin{tabular}{|c|c|}
\hline $\begin{array}{l}\text { PMS FSSP } 300 \text { or 2DC-grey or DMT } \\
\text { CIP }\end{array}$ & Cloud particle size distribution \\
\hline Korolev Cloud Extinction Meter & Cloud Extinction \\
\hline \multicolumn{2}{|r|}{ Aerosol } \\
\hline TSI 3775 & Total particle concentration (> $3 \mathrm{~nm})$ \\
\hline $\begin{array}{l}\text { Passive Cavity Aerosol Spectrometer } \\
\text { (PMS PCASP-100X)/ Ultra-High } \\
\text { Sensitivity Aerosol Spectrometer } \\
\text { (DMT-SPP-200) }\end{array}$ & Aerosol size distribution $(100-3000 \mathrm{~nm})$ \\
\hline DMT CCN counter & CCN concentration \\
\hline Continuous Flow Diffusion Chamber & Ice nucleus concentration \\
\hline $\begin{array}{l}\text { Radiance Particle/Soot Absorption } \\
\text { Photometer }\end{array}$ & Mass of black carbon \\
\hline Nephelometer (TSI 3563) & Optical scattering \\
\hline 3 laser Photo-acoustic spectrometer & Aerosol absorption and scattering $(405,532$ and $781 \mathrm{~nm})$ \\
\hline DMT Soot Photometer (SP2)\# & $\begin{array}{l}\text { Refractory (black carbon and dust) particle mass } \\
\text { distribution }\end{array}$ \\
\hline Aerosol Mass Spectrometer & Size-resolved composition (non-refractory) \\
\hline $\begin{array}{l}\text { Single Particle Laser Ablation Time of } \\
\text { flight mass spectrometer }\end{array}$ & $\begin{array}{l}\text { Single particle size-resolved composition (refractory and } \\
\text { non-refractory material) }\end{array}$ \\
\hline Time-Resolved Aerosol Collector & Time-resolved substrate for lab analysis $(0.1-7 \mu \mathrm{m})$ \\
\hline $\begin{array}{l}\text { Scanning Electron Microscope (linked } \\
\text { with TRAC) }\end{array}$ & Single aerosol particle analysis \\
\hline \multicolumn{2}{|r|}{ Radiometers } \\
\hline $\begin{array}{l}\text { Heitronics KT19.85 Infrared } \\
\text { Thermometer }\end{array}$ & Cloud emissivity; Nadir view, narrow field of view \\
\hline Broadband visible radiometers & $\begin{array}{l}\text { Hemispheric radiometers }(305-2800 \mathrm{~nm}) \text {, zenith and } \\
\text { nadir }\end{array}$ \\
\hline $\begin{array}{l}\text { Broadband Pyrgeometers (Epply } 3.5- \\
50 \mu \mathrm{m})\end{array}$ & Hemispheric infrared fluxes, zenith and nadir view \\
\hline \multicolumn{2}{|c|}{ Aerosol Sample Collection } \\
\hline Aerosol inlet & Isokinetic aerosol inlet \\
\hline Counter-flow Virtual Impactor & Separation of residual aerosol \\
\hline \multicolumn{2}{|r|}{ Remote Sensing } \\
\hline Ka-band up/down looking radar & Radar cross sections \\
\hline $\begin{array}{l}\text { ProSensing up-looking G-band } \\
\text { radiometer }\end{array}$ & Water vapor and liquid water path above aircraft \\
\hline $\begin{array}{l}\text { X-band/W-band Doppler radar, dual } \\
\text { polarization, up/down/side looking }\end{array}$ & radar cross sections, hydrometeor type identification \\
\hline
\end{tabular}

\# pending approval.

The temperature and dew-point temperature are needed to determine specific and relative humidity, which are essential for distinguishing different ice nucleation mechanisms and for accounting for the effects of humidification on aerosol extinction. The aerosol inlet and CVI are needed to collect aerosols from clear air and cloud particles, respectively; as illustrated in Figure 6, the aerosol instruments draw from the aerosol inlet when below, between, or above cloud layers, and from the CVI when within cloud layers. The Time-Resolved Aerosol Collector (TRAC) will collect particles on a substrate with a roughly 1 minute time resolution; the collected particles can then be examined in a laboratory with Computer- 


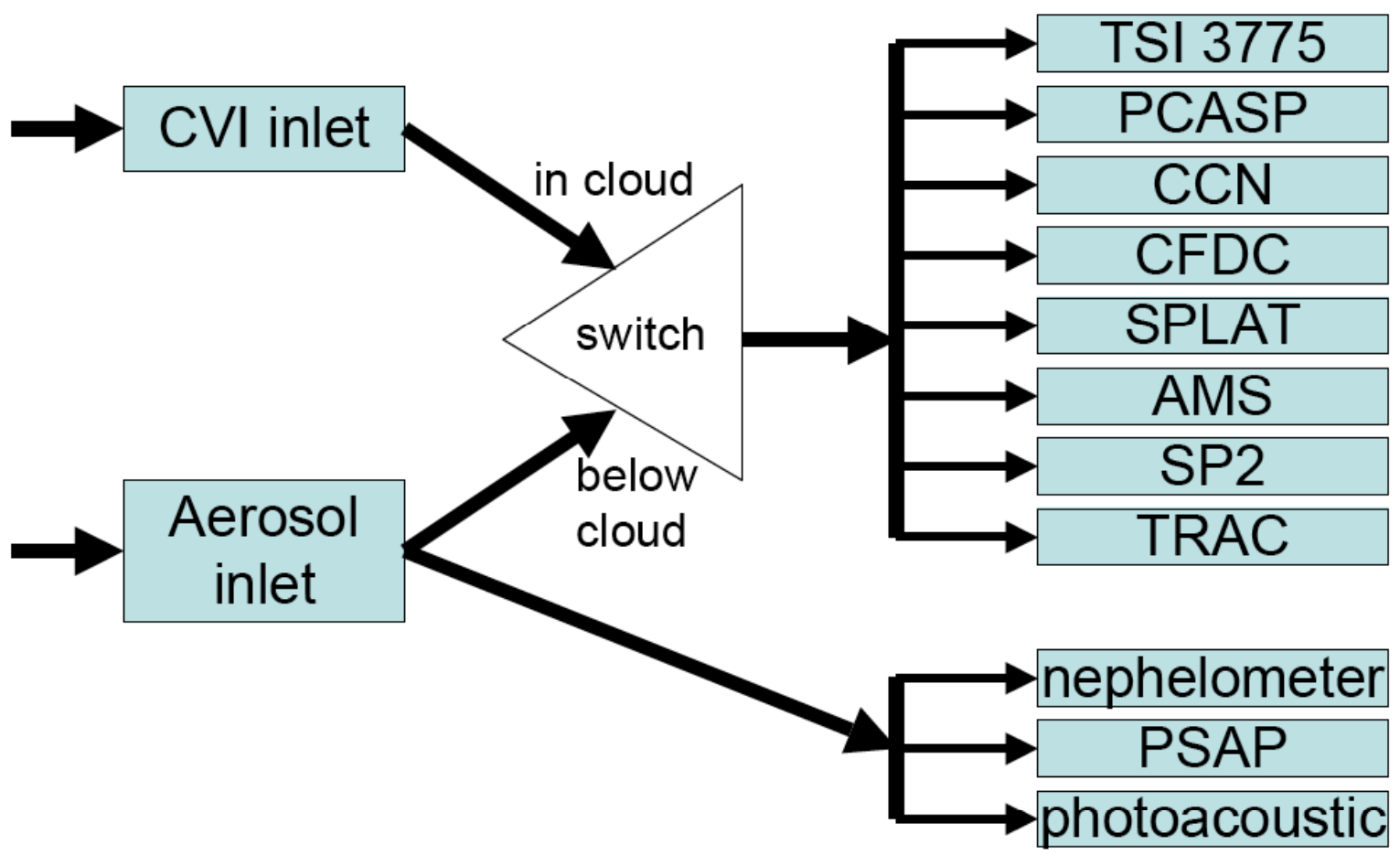

Figure 6: Configuration of aerosol instruments in aircraft. The switch is manually set for instruments to draw from aerosol inlet when not in cloud, and to draw from CVI inlet when in cloud.

Controlled Scanning Electron Microscopy with Energy Dispersed detection of X-rays (CCSEM/EDX) (Laskin et al., 2003). The passive cavity aerosol spectrometer probe (PCASP) measures the aerosol size distribution for the diameter range 0.1-3 $\mu \mathrm{m}$. The DMT CCN instrument measures CCN concentration at multiple supersaturations sequentially over a period of minutes. The TSI 3775 provides better time resolution (1 second) than the $\mathrm{CCN}$ and hence, can be used to scale the measured CCN concentration. The CFDC will provide measurements of IN concentration at a variety of selected supersaturations, which are needed as input for cloud models and can be used to distinguish between primary and secondary ice nucleation. The aerosol mass spectrometer will provide size-resolved composition information for the non-refractory aerosol. If approved, the SP2 would provide size-distributions of the refractory aerosol. The single-particle mass spectrometer would provide size distribution of composition, including refractory as well as salts and organic, and mixtures. These latter two instruments will be invaluable for identifying the size and composition of droplet and ice crystal nuclei.

The optical properties of the aerosol, in particular the mixing state of black carbon that has been implicated in Arctic pollution and radiative forcing, will be measured by 3 independent methods. The PSAP and nephelometers will provide absorption and scattering by aerosols respectively. A new 3-laser photo-acoustic (LAPA-3) will be deployed to measure both absorption and scattering directly at 405, 532, and $781 \mathrm{~nm}$ to determine the single scatter albedo with high confidence at these wavelengths. Finally the SP2 will measure the single particle optics. These there independent observations will yield significant information on the processes controlling aerosol optical properties and their transition from the winter to spring season. In conjunction with other cloud microphysical measurements they will provide information on the mechanisms by which absorbing aerosols can be deposited on the ice/snow surface that has been shown to be important to Arctic forcing. 
The cloud particle imager (CPI) provides high-resolution $(2.3 \mu \mathrm{m})$ images of cloud particles on a CCD array which can be used to identify particle phase and ice crystal habit or habits that may give information about ice crystal nucleation mechanisms when compared to results of laboratory studies. Although the CPI has a smaller sample volume than some cloud probes, size distributions (SDs) can be estimated when integrating over longer ( $\sim 1$ minute) periods. The CPI SDs are needed for the 50 to $125 \mu \mathrm{m}$ range not well sampled by other probes. The cloud aerosol and precipitation spectrometer (CAPS) combines a cloud and aerosol spectrometer (CAS), a cloud imaging probe (CIP), and a hot-wire liquid water sensor in a single probe. SDs of particles smaller than $50 \mu \mathrm{m}$ will be obtained from the CAS. The CIP nominally provides SDs between 25 and $1550 \mu \mathrm{m}$, but in reality only between 125 and $1550 \mu \mathrm{m}$ because optical array probes do not well measure particles smaller than $125 \mu \mathrm{m}$ at typical aircraft speeds (Baumgardner and Korolev 1997). The CIP provides statistically significant observations of SDs for sizes above $125 \mu \mathrm{m}$; it also provides lower resolution $(25 \mu \mathrm{m})$ images of ice crystals.

Although the CIP, CAS, CDP, and CPI measure SDs, bulk measurements of cloud mass and extinction are required to avoid assumptions about poorly defined mass-diameter and area-diameter relationships that depend on crystal habit. The cloud spectrometer and impactor (CSI) measures the total water content (TWC) within $1 \mathrm{mg} \mathrm{m}^{-3}$ by evaporating ice particles with $\mathrm{D}>5 \mu \mathrm{m}$ in dry air and has been extremely reliable in past ARM field campaigns. The TWC is identical to the ice water content (IWC) in an icephase cloud. The TWC combined with bulk measures of LWC from a King probe would allow a determination of IWC in a mixed-phase cloud. The Nevzorov probe also provides TWC and LWC and hence IWC, but with the $0.1 \mathrm{~s}$ time ( $10 \mathrm{~m}$ horizontal for $100 \mathrm{~ms}^{-1}$ flight speed) resolution needed to isolate nucleation mechanisms and characterize the fine scale interface between water and ice and provides finer resolution observations of IWC. The cloud extinction meter provides direct measurements of the radiative significance of the cloud (important for indirect effect studies), and in combination with the CSI and SDs can be used to determine the effective radius of the cloud particles.

All data will be processed and placed in netcdf format in the ACRF Archive. For the cloud extinction probe, estimates of extinction coefficient will be placed in the archive. For the CSI, estimates of TWC will be made available. The SDs from the CAPS and CPI can be generated in netcdf form using software developed at the University of Illinois following procedures developed during the Tropical Warm PoolInternational Cloud Experiment (TWP-ICE) to process the CAPS data (G. McFarquhar of Illinois). The CPI images will also be generated for the Archive (G. McFarquhar of Illinois). All state parameters, location and bulk LWC data will be processed and made available by the platform PI. The required boundary conditions for driving cloud models will be derived from the ECMWF analysis constrained with observations from this field campaign using variational analysis (S. Xie of Lawrence Livermore National Laboratory).

This set of instruments is similar to those deployed for M-PACE, but with a few substitutions, extensions and omissions. The CAPS probe will be flow together with the forward scattering spectrometer probe and 2D-C used for M-PACE. The TSI-3775, PSAP for measuring aerosols, the Nevzorov and cloud extinction meter for measuring bulk cloud properties and the spectroradiometer are important additions. The TRAC, AMS, SP2 and single-particle mass spectrometer will be valuable for characterizing aerosol particle composition. M-PACE instruments not deployed for ISDAC include observations used on multiple Aerosondes (wind, temperature, humidity and pressure sensors, aerosol counters and ice particle imagers). 
In addition to the proposed aircraft measurements, this experiment will rely on instruments and measurements at the ACRF NSA site and at the NOAA Earth Systems Research Laboratory (ESRL) Barrow facility. These instruments and measurements are listed in Tables 2 and 3, respectively.

Table 2: Instruments and measurements at ACRF Barrow site.

\begin{tabular}{|l|l|}
\hline \multicolumn{1}{|c|}{ Instrument } & \multicolumn{1}{c|}{ Measurements } \\
\hline Radiosonde & Temperature, humidity, winds profiles \\
\hline Microwave radiometer* & Water vapor path, liquid water path \\
\hline Microwave radiometer profiler & Temperature, humidity, LWC profile \\
\hline $915 \mathrm{MHz}$ radar wind profiler/RASS & Winds, virtual temperature profile \\
\hline Vaisala Ceilometer* & Cloud base altitude \\
\hline Millimeter cloud radar & Cloud liquid water, cloud ice content profiles \\
\hline Micropulse lidar (polarized) & Aerosol backscatter profile, depolarization ratio \\
\hline AERI & $\begin{array}{l}\text { Temperature, humidity profiles, water path, optical } \\
\text { depth, and effective radius of the ice and water } \\
\text { component of mixed-phase clouds }\end{array}$ \\
\hline Cimel sunphotometer & Aerosol optical depth \\
\hline Multi-Filter Shadowband Radiometer & $\begin{array}{l}\text { Aerosol optical depth at multiple wavelengths } \\
\text { cloud optical depth, cloud fraction }\end{array}$ \\
\hline Normal incidence multifilter radiometer & Aerosol optical depth \\
\hline Upviewing radiometers* & Downward longwave, solar irradiance \\
\hline Downviewing radiometers & \\
\hline Spectroradiometer \# & Upward longwave, solar irradiance \\
\hline TDMA \# & Downwelling irradiance or zenith radiance $0.35-2.5 \mu \mathrm{m}$ \\
\hline Hotplate rain gauge & Size resolved aerosol hygroscopicity $(0.015-0.6 \mu \mathrm{m})$ \\
\hline
\end{tabular}

*Atqasuk also \# ISDAC only

Table 3: Instruments and measurements at ESRL Barrow site.

\begin{tabular}{|l|l|}
\hline \multicolumn{1}{|c|}{ Instrument } & \multicolumn{1}{c|}{ Measurement } \\
\hline Humidified nephelometer & Aerosol scattering as $\mathrm{f}(\mathrm{RH})$ \\
\hline PSAP & Aerosol absorption \\
\hline Condensation nuclei counter & Total particle number \\
\hline PCASP & Accumulation mode size distribution \\
\hline CCN & CCN concentration a multiple supersaturations \\
\hline Daily chemical analysis & Submicron mass, ion concentration \\
\hline Radiometers & Radiance, aerosol optical depth \\
\hline Snow gauge & Snowfall \\
\hline
\end{tabular}

In addition to the instruments deployed for long-term measurements at the surface sites, for ISDAC we will also deploy two additional instruments at the NSA surface site: a spectroradiometer and a tandem differential mobility analyzer (TDMA). The spectroradiameter will be used for retrieving cloud optical depth $(\tau)$ and effective radius $\left(\mathrm{r}_{\mathrm{e}}\right)$, and for quantifying aerosol impacts on shortwave radiation. This instrument, an Analytical Spectral Devices (ASD, Inc.) FieldSpec owned by the Scripps Institution of 
Oceanography, measures downwelling irradiance or zenith radiance from $0.35-2.5 \mu \mathrm{m}$, and thus covers 3 atmospheric windows in which downwelling radiation is sensitive to $\tau$, thermodynamic phase, and $r_{e}$ (Nakajima and King 1990; Dong et al. 1997; Pilewskie et al. 1998). At the NSA site, a narrowband spectral radiometer of MFRSR has been deployed for many years. MFRSR simultaneously measures direct and diffuse irradiances at six passbands, which allows one to infer cloud fraction and cloud optical depths from optically thin clouds to very thick clouds (Min and Harrison, 1996; Min et al, 2004). Previous radiometric work on the indirect effect has used the AERI (Lubin and Vogelmann 2006; Garrett and Zhao 2006), but AERI retrievals are limited to IWPs between 5-250 $\mathrm{g} \mathrm{m}^{-2}$, LWPs between 5-80 $\mathrm{g} \mathrm{m}^{-2}$, and $\tau<8$ (Turner 2005) for which the cloud radiates as a greybody with spectral dependence. Retrievals based on transmitted solar near-infrared spectral radiance are not subject to this limitation. However, AERI retrievals are advantageous in that they work in the range in which the microwave radiometer performs poorly, and $80 \%$ of liquid arctic clouds have LWP $<100 \mathrm{~g} \mathrm{~m}^{-2}$ (Dave Turner, ARM presentation). Therefore, the combination of the ASD, the MFRSR and the AERI can provide microphysical retrievals under all cloud conditions. Further, the AERI time series of small ice crystal concentrations (i.e., the small particle mode of the SD) can be related to time series of the aerosol PSD at NSA and Kuparuk. If a subset of the aerosol population is initiating new ice crystals, the small mode of the PSD should be proportional to this subset. ASD measurements, in conjunction with broadband shortwave radiometers at NSA, will also reveal directly which component of the indirect effectshortwave cooling or longwave warming-is dominant under any given meteorological condition. This determination of the sign of aerosol radiative forcing is critical information for the climate modeling community.

The tandem differential mobility analyzer (TDMA) measures the size distribution of aerosol number and hygroscopicity for the diameter range 0.01-0.6 $\mu \mathrm{m}$. This instrument was placed on the ground because its measurements are most valuable below cloud, but cloud base is usually too low for aircraft flights below cloud. The measured size distribution can be combined with the size-resolved estimate of hygroscopicity to (a) test the Köhler treatment of the CCN spectrum, which can be compared with the CCN concentration measured at a selected supersaturation (Gasparini et al., 2006a), (b) test droplet nucleation models and parameterizations using the measured vertical velocity and droplet number concentration (Meskhidze et al. 2005), and (c) to provide aerosol inputs to cloud models. Although hygroscopicity measurements require much more time (15 minutes) than size distribution measurements ( 1.5 minutes), recent work by Dusek et al. (2006) suggests that most variability in CCN spectrum is due to variability in size distribution rather than hygroscopicity.

\section{Applications}

This field campaign will provide the data needed to achieve each of the primary objectives. By using many of the same instruments used during M-PACE, we will be able to contrast the arctic aerosol and cloud properties during October and April. Table 4 summarizes the expected applications of ISDAC data. The context of these applications has been previously described in the background and motivation of the proposal. The aerosol measurements will be used in cloud models driven by objectively analyzed boundary conditions to test whether the cloud models can simulate the aerosol influence on the clouds. The influence of aerosol and boundary conditions on the simulated clouds will be separated by running the cloud models with all four combinations of M-PACE and ISDAC aerosol and boundary conditions: M-PACE aerosol and boundary conditions, M-PACE aerosol and ISDAC boundary conditions, ISDAC aerosol and M-PACE boundary conditions, and ISDAC aerosol and boundary conditions. ISDAC and MPACE boundary conditions are likely to be very different because of the much more extensive ocean 
water during M-PACE. The uniformity of the surface conditions during ISDAC greatly simplifies the objective analysis (surface fluxes and precipitation are very weak), so that it can largely rely on the ECMWF analysis. The ISDAC cloud measurements will be used to improve understanding of crystal nucleation, to evaluate the cloud simulations and to evaluate cloud retrievals. The aerosol measurements will also be used to evaluate the aerosol retrievals that, once validated, can be used in long-term studies of aerosol effects on clouds. By running the cloud models with and without solar absorption by the aerosols, we will determine the semi-direct effect of the aerosol on the clouds.

The ice particle shattering issue will be addressed by pooling all types of ice particle measurements to evaluate the level of internal consistency between measurements and to evaluate the level of ice particle shattering that occurs during in situ sampling.

The aircraft measurements are also sorely needed to evaluate and further develop cloud retrievals from the ground-based instruments at the NSA locale. ARM investigators have developed numerous methods for deriving cloud and precipitation properties from various combinations of radar, lidar, AERI, and microwave radiometer measurements. Each of these instruments provides a unique perspective on cloud properties based on the individual instrument specifications. A full characterization of cloud properties requires a coordinated retrieval framework that can incorporate each of these instruments under the appropriate conditions. Some of this retrieval coordination effort is under way within the ARM community in support of accurate, operational heating rate calculations. The ISDAC cloud measurements will be directly and statistically compared to the coordinated surface retrieval results. Particular focus will be placed on evaluating the ability of the surface retrievals to partition cloud water appropriately between phases and to accurately estimate the cloud liquid water under the low liquid water conditions expected in April. Furthermore, surface-based cloud retrievals can be coordinated with measurements of $\mathrm{CCN}$, IN, and/or vertical velocities to examine various processes that impact the cloud properties, the cloud persistence, and the cloud-aerosol interaction.

Table 4: Applications of ISDAC data.

\begin{tabular}{|c|c|c|c|c|}
\hline $\begin{array}{c}\text { Experiment } \\
\text { Lead }\end{array}$ & Input Data & Instrument & Validation data & Instrument \\
\hline \multirow{3}{*}{$\begin{array}{l}\text { CCN closure } \\
\text { Don Collins }\end{array}$} & Aerosol size dist 10-750 nm & DMA & \multirow[t]{3}{*}{ CCN concentration } & \multirow[t]{3}{*}{ DMT CCN } \\
\hline & Aerosol size dist $100-3000 \mathrm{~nm}$ & PCASP & & \\
\hline & Hygroscopicity size dist $15-600 \mathrm{~nm}$ & TDMA & & \\
\hline \multirow{4}{*}{$\begin{array}{l}\text { Droplet } \\
\text { number } \\
\text { closure } \\
\text { Steven Ghan }\end{array}$} & Aerosol size dist $10-750 \mathrm{~nm}$ & DMA & \multirow[t]{4}{*}{ Droplet number concentration } & \multirow[t]{4}{*}{ CAPS-CAS } \\
\hline & Aerosol size dist $100-3000 \mathrm{~nm}$ & PCASP & & \\
\hline & Hygroscopicity size dist $15-600 \mathrm{~nm}$ & TDMA & & \\
\hline & Vertical velocity & Gust probe & & \\
\hline \multirow{4}{*}{$\begin{array}{l}\text { Cloud } \\
\text { extinction } \\
\text { closure } \\
\text { Greg } \\
\text { McFarquhar }\end{array}$} & Cloud particle size dist $0.5-50 \mu \mathrm{m}$ & CAPS-CAS & \multirow[t]{4}{*}{ Cloud extinction } & \multirow{4}{*}{$\begin{array}{l}\text { Cloud } \\
\text { extinction } \\
\text { probe }\end{array}$} \\
\hline & Cloud part size dist 50-1000 $\mu \mathrm{m}$ & 2DS & & \\
\hline & Cloud part size dist $125-1500 \mu \mathrm{m}$ & CAPS-CIP & & \\
\hline & Cloud part size dist $1200-6400 \mu \mathrm{m}$ & 2DP & & \\
\hline
\end{tabular}


Table 4: (contd.)

\begin{tabular}{|c|c|c|c|c|}
\hline $\begin{array}{l}\text { Experiment } \\
\text { Lead }\end{array}$ & Input Data & Instrument & Validation data & Instrument \\
\hline \multirow{4}{*}{$\begin{array}{l}\text { Cloud water } \\
\text { closure } \\
\text { Greg } \\
\text { McFarquhar }\end{array}$} & Cloud particle size dist $0.5-50 \mu \mathrm{m}$ & CAPS-CAS & \multirow[t]{4}{*}{ Total water content (TWC) } & \multirow[t]{3}{*}{ DMT CSI } \\
\hline & Cloud part size dist 50-1000 $\mu \mathrm{m}$ & 2DS & & \\
\hline & Cloud part size dist $125-1500 \mu \mathrm{m}$ & CAPS-CIP & & \\
\hline & Cloud part size dist $1200-6400 \mu \mathrm{m}$ & 2DP & & Nevzorov \\
\hline \multirow{10}{*}{$\begin{array}{l}\text { Cloud } \\
\text { modeling } \\
\text { Ann Fridlind }\end{array}$} & \multirow[t]{2}{*}{ Aerosol size dist $10-750 \mathrm{~nm}$} & \multirow[t]{2}{*}{ DMA } & Cloud particle size dist $0.5-50 \mu \mathrm{m}$ & CAPS-CAS \\
\hline & & & Cloud part size dist 50-1000 $\mu \mathrm{m}$ & $2 \mathrm{DS}$ \\
\hline & Aerosol size dist $100-3000 \mathrm{~nm}$ & PCASP & Cloud part size dist $125-1500 \mu \mathrm{m}$ & CAPS-CIP \\
\hline & & & Cloud part size dist $1200-6400 \mu \mathrm{m}$ & 2DP \\
\hline & \multirow[t]{2}{*}{ Hygroscopicity size dist 15-600 nm } & \multirow[t]{2}{*}{ TDMA } & \multirow[t]{2}{*}{ Liquid water content (LWC) } & King probe \\
\hline & & & & Nevzorov \\
\hline & Ice nuclei conc $(T, S)$ & CFDC & \multirow[t]{2}{*}{ TWC } & DMT CSI \\
\hline & Downward longwave at model top & pyrgeometer & & Nevzorov \\
\hline & $\mathrm{u}, \mathrm{v}, \mathrm{T}, \mathrm{q}$ & $\begin{array}{l}\text { ECMWF } \\
\text { analysis }\end{array}$ & precipitation & $\begin{array}{l}\text { Hot-plate rain } \\
\text { gauge }\end{array}$ \\
\hline & $\begin{array}{l}\text { Surface fluxes \& large-scale } \\
\text { forcing profiles }\end{array}$ & $\begin{array}{l}\text { ECMWF } \\
\text { analysis }\end{array}$ & Cloud extinction & $\begin{array}{l}\text { Cloud } \\
\text { extinction } \\
\text { probe }\end{array}$ \\
\hline \multirow[t]{3}{*}{$\begin{array}{l}\text { Semi-direct } \\
\text { effect } \\
\text { Ann Fridlind }\end{array}$} & $\begin{array}{l}\text { Same as for cloud modeling, plus } \\
\text { the following }\end{array}$ & $\begin{array}{l}\text { Same as for } \\
\text { cloud modeling, } \\
\text { plus }\end{array}$ & \multirow[t]{3}{*}{ Same as for cloud modeling } & \multirow[t]{3}{*}{$\begin{array}{l}\text { Same as for } \\
\text { cloud } \\
\text { modeling }\end{array}$} \\
\hline & Aerosol absorption & $\begin{array}{l}\text { PSAP, photo- } \\
\text { acoustic }\end{array}$ & & \\
\hline & Aerosol scattering & nephelometer & & \\
\hline $\begin{array}{l}\text { Ice crystal } \\
\text { nucleation } \\
\text { Sarah Brooks }\end{array}$ & $\begin{array}{l}\text { Size-resolved composition of } \\
\text { residual aerosol }\end{array}$ & $\begin{array}{l}\text { Single-particle } \\
\text { mass } \\
\text { spectrometer } \\
\text { Counterflow } \\
\text { virtual impactor }\end{array}$ & $\mathrm{IN}(\mathrm{T}, \mathrm{S})$ & CFDC \\
\hline \multirow{5}{*}{$\begin{array}{l}\text { Relation } \\
\text { between IN } \\
\text { and ice crystal } \\
\text { concentration } \\
\text { Greg } \\
\text { McFarquhar }\end{array}$} & IN $\left(T, S_{i}\right)$ & CFDC & Crystal size and habit & SPEC CPI \\
\hline & temperature & $\begin{array}{l}\text { Rosemont } \\
\text { probe }\end{array}$ & Cloud particle size dist $0.5-50 \mu \mathrm{m}$ & CAPS-CAS \\
\hline & \multirow[t]{2}{*}{ humidity } & LICOR & Cloud particle size dist 50-1000 $\mu \mathrm{m}$ & $2 \mathrm{DS}$ \\
\hline & & $\begin{array}{l}\text { chilled-mirror } \\
\text { hygrometer }\end{array}$ & Cloud part size dist $125-1500 \mu \mathrm{m}$ & CAPS-CIP \\
\hline & water-ice interface & Nevzorov & Cloud part size dist $1200-6400 \mu \mathrm{m}$ & 2DP \\
\hline \multirow{2}{*}{$\begin{array}{l}\text { Aerosol } \\
\text { extinction } \\
\text { closure } \\
\text { Claudio } \\
\text { Mazzonleni } \\
\end{array}$} & Aerosol size distribution & DMA, PCASP & Aerosol scattering & nephelometer \\
\hline & Aerosol composition & AMS, SPLAT & Aerosol absorption & $\begin{array}{l}\text { PSAP, photo- } \\
\text { acoustic }\end{array}$ \\
\hline \multirow{2}{*}{$\begin{array}{l}\text { Aerosol } \\
\text { extinction } \\
\text { retrieval } \\
\text { Connor Flynn }\end{array}$} & \multirow[t]{2}{*}{ Aerosol extinction } & \multirow[t]{2}{*}{ MPL } & Aerosol scattering & nephelometer \\
\hline & & & Aerosol absorption & $\begin{array}{l}\text { PSAP, photo- } \\
\text { acoustic }\end{array}$ \\
\hline
\end{tabular}


Table 4: (contd.)

\begin{tabular}{|c|c|c|c|c|}
\hline $\begin{array}{l}\text { Experiment } \\
\text { Lead }\end{array}$ & Input Data & Instrument & Validation data & Instrument \\
\hline \multirow{5}{*}{$\begin{array}{l}\text { CCN retrieval } \\
\text { Steven Ghan }\end{array}$} & Aerosol backscatter & MPL & \multirow[t]{5}{*}{$\mathrm{CCN}$} & \multirow[t]{5}{*}{ DMT CCN } \\
\hline & Aerosol scattering & MPL & & \\
\hline & Relative humidity retrieval & RASS & & \\
\hline & Surface CCN & Surface CCN & & \\
\hline & humidification function & Surface neph & & \\
\hline \multirow{2}{*}{$\begin{array}{l}\text { MMCR } \\
\text { retrievals } \\
\text { Matthew } \\
\text { Shupe }\end{array}$} & \multirow[t]{2}{*}{ radar reflectivity, } & \multirow[t]{2}{*}{ MMCR } & LWC & $\begin{array}{l}\text { King probe } \\
\text { Nevzorov }\end{array}$ \\
\hline & & & TWC & $\begin{array}{l}\text { DMT CSI } \\
\text { Nevzorov }\end{array}$ \\
\hline $\begin{array}{l}\text { MWR } \\
\text { retrievals } \\
\text { David Turner }\end{array}$ & microwave radiance & MWR & LWC & $\begin{array}{l}\text { King probe } \\
\text { Nevzorov }\end{array}$ \\
\hline \multirow[t]{7}{*}{$\begin{array}{l}\text { AERI retrievals } \\
\text { David Turner }\end{array}$} & \multirow[t]{7}{*}{ Infrared radiance spectrum } & \multirow[t]{7}{*}{ AERI } & TWC & $\begin{array}{l}\text { DMT CSI } \\
\text { Nevzorov }\end{array}$ \\
\hline & & & LWP & $\begin{array}{l}\text { King probe } \\
\text { Nevzorov }\end{array}$ \\
\hline & & & Cloud particle size dist $0.5-50 \mu \mathrm{m}$ & CAPS-CAS \\
\hline & & & Cloud particle size dist $50-1000 \mu \mathrm{m}$ & 2DS \\
\hline & & & Cloud part size dist $125-1500 \mu \mathrm{m}$ & CAPS-CIP \\
\hline & & & Cloud part size dist $1200-6400 \mu \mathrm{m}$ & 2DP \\
\hline & & & Cloud extinction & $\begin{array}{l}\text { Cloud } \\
\text { extinction } \\
\text { probe }\end{array}$ \\
\hline $\begin{array}{l}\text { ASD retrievals } \\
\text { Dan Lubin }\end{array}$ & solar radiance spectrum & $\begin{array}{l}\text { ASD spectro- } \\
\text { radiometer }\end{array}$ & Same as for AERI & $\begin{array}{l}\text { Same as for } \\
\text { AERI }\end{array}$ \\
\hline $\begin{array}{l}\text { MFRSR } \\
\text { retrieval } \\
\text { Qilong Min }\end{array}$ & $\begin{array}{l}\text { direct and diffuse radiance at } \\
\text { multiple solar wavelengths }\end{array}$ & MFRSR & $\begin{array}{l}\text { Aerosol scattering and absorption. } \\
\text { Cloud extinction and particle size }\end{array}$ & $\begin{array}{l}\text { nephelometer } \\
\text { PSAP } \\
\text { Photo- } \\
\text { acoustic } \\
\text { Cloud probes }\end{array}$ \\
\hline $\begin{array}{l}\text { Radiative } \\
\text { closure } \\
\text { Eli Mlawer }\end{array}$ & $\begin{array}{l}\text { Vertical profiles of cloud properties, } \\
\mathrm{T}, \mathrm{q}\end{array}$ & $\begin{array}{l}\text { MMCR, MPL, } \\
\text { ceilometer, } \\
\text { MWR, AERI }\end{array}$ & Longwave irradiance profile & pyrgeometers \\
\hline $\begin{array}{l}\text { Full Flux } \\
\text { Analysis } \\
\text { Charles Long }\end{array}$ & $\begin{array}{l}\text { Surface direct and diffuse SW and } \\
\text { LW radiance, temperature }\end{array}$ & $\begin{array}{l}\text { Surface } \\
\text { radiometers, } \\
\text { tower met insts. }\end{array}$ & cloud optical depth & $\begin{array}{l}\text { Cloud } \\
\text { extinction } \\
\text { probe }\end{array}$ \\
\hline
\end{tabular}

\section{Experiment Plan}

A total of 94 flight hours are allocated for ISDAC. The primary base of operations will be in Fairbanks, about $800 \mathrm{~km}$ south of Barrow. All flights will be based out of Fairbanks, where hangar space is available. Research sorties will consist of flights from Fairbanks to Barrow, sampling in the vicinity of Barrow for 2 hours, landing and refueling at Barrow, additional sampling above Barrow for 3 hours, and then returning to Fairbanks for a total of 8.5 hours of flight on the sortie. A total of 11 sorties are expected, about 2.5 per week. 
Detailed flight profiles for the experiment are available in a separate mission description document that includes flight profiles associated with specific science objectives. Here, only general descriptions of desired flight profiles are provided. ISDAC science requirements favor horizontal flight legs because of the 2-3 minute duty cycle of several aerosol instruments. In general, flights should begin with sampling of clear air, followed by sampling of glaciated cloud, leaving sampling of liquid and mixed phase clouds for the last portion of the flight. This strategy maximizes the duration of sampling through the aerosol inlets, which can become clogged with ice within minutes under icing conditions. Thus, ISDAC flights above Barrow should be used first to collect aerosol measurements above cloud, between clouds, and if possible below cloud. For all flight tracks through cloud-free air the aerosol instruments will draw samples from the aerosol inlet rather than the CVI. Measurements at multiple levels should be performed, minimizing time within liquid cloud until all measurements outside cloud are complete. It should be feasible to perform horizontal legs at 10 levels in 40 minutes (allowing 1 minute to move from one level to another). Once these stair steps are complete (flying over the ARM site for each horizontal leg), horizontal legs through clouds can be performed. The aerosol sampling should draw from the CVI for flight tracks predominantly through clouds. These should begin with the glaciated layers to minimize the threat of icing. Horizontal legs of at least 15 minutes (about $90 \mathrm{~km}$ ) should be performed. There should be time for at least three cloud legs before sampling liquid cloud. When flying through cloud the background wind will be carefully examined to set flight patterns that avoid resampling of previously measured cloud areas that may be contaminated by aircraft-produced ice particles (Woodley et al. 2003). Although icing is always a concern in the Arctic, our experience during M-PACE suggests cloud probes could sustain operation for at least 40-50 minutes at an average liquid water of $0.1 \mathrm{~g} \mathrm{~m}^{-3}$; analysis of SHEBA data for April suggests lower LWCs and smaller droplets than those encountered during M-PACE, so that de-icing will probably not be necessary for horizontal legs through liquid clouds for less than 15 minutes. Actual flight profiles will be subject to aircraft and air traffic control limitations. Further details on flight plans are provided in the ISDAC Flight Planning Document.

\section{Management}

The multiple objectives of ISDAC demand careful planning to ensure that the objectives of the campaign are met. It is important that the planning process is open. However, decisions will be made by a small group of individuals with the discussion facilitated by the NSA Site Scientist Hans Verlinde, who is also an ISDAC Co-PI. In addition to Hans Verlinde, the decision making group will include the following people: Steven Ghan (ISDAC PI), Beat Schmid (AVP Technical Director), Greg McFarquhar (AVP Chief Scientist), Walter Strapp and/or Alexei Korolev (Environment Canada) and Mengistu Wolde and/or Matthew Bastian/Dave Marcotte (National Research Council Canada). Forecasting support will be provided by the NSA Site Scientist Team from Penn State. Responsibilities for each investigator are summarized in Table 5. The instrument mentors will be responsible for the calibration of their instrument, integration with the platform, operation during the campaign, removal of the instrument from the platform, data processing, and data archiving. 
Table 5: Investigator responsibilities.

\begin{tabular}{|l|l|}
\hline Investigator & Responsibility \\
\hline Steven Ghan & ISDAC lead, cloud modeling, CCN retrieval \\
\hline Beat Schmid & AVP Technical Director \\
\hline Mengistu Wolde & $\begin{array}{l}\text { National Research Council Convair-580 aircraft, aircraft state parameters, gust } \\
\text { probe, GVR (183 GHz radiometer) and NAWX radar. }\end{array}$ \\
\hline Walter Strapp and others & $\begin{array}{l}\text { Mentor for Rosemont 102, chilled mirror hygrometer, LICOR, aerosol inlet, TSI } \\
\text { 3775, PCASP, PSAP, CAPS, CSI, 2DP, nephelometer, gust probe, King probe }\end{array}$ \\
\hline Anne-Marie McDonald & Mentor for CVI \\
\hline Alexi Korelev & Mentor for Nevzorov, extinctometer \\
\hline Peter Liu & Aerosol instrument integration \\
\hline Don Collins & Mentor for DMA, TDMA, CCN counter \\
\hline Sarah Brooks & Mentor for CFDC \\
\hline Greg McFarquhar & AVP Chief Scientist, Mentor for CPI \\
\hline Paul Lawson & Analysis of 2DS data \\
\hline Alex Laskin & Mentor for TRAC \\
\hline Alla Zelenyuk & Mentor for SPLAT \\
\hline M. Dubey /C. Mazzoleni & Mentor for 3 laser photoacoustic \\
\hline Dan Lubin & Mentor for spectroradiometer, cloud retrievals \\
\hline Hans Verlinde & NSA site scientist, cloud retrievals \\
\hline Ann Fridlind & Cloud modeling \\
\hline Shaocheng Xie & Boundary conditions for cloud models \\
\hline Connor Flynn & Aerosol retrievals \\
\hline Matthew Shupe & Cloud retrievals \\
\hline David Turner & Cloud retrievals \\
\hline Tim Garrett & Cloud retrievals \\
\hline David Mitchell & Cloud retrievals \\
\hline Jay Mace & Cloud retrievals \\
\hline Qilong Min & MFRSR retrievals \\
\hline Eli Mlawer & BBHRP retrievals \\
\hline Chuck Long & Radiometer retrievals, Convair radiometers \\
\hline & \\
\hline
\end{tabular}

Plots of the preliminary data from each flight will be made available within one day of each flight on the NSA site scientist team web site (http://nsa.met.psu.edu/; similar to what was done for M-PACE) for inspection by the science teams. Each week's results will be discussed and evaluated during a weekly steering committee meeting to see if project objectives are being met, and whether any adjustments to the sampling strategy are necessary. The same web-site will also present quick look images of ARM surface based remote sensing measurement: the site scientist team will provide daily inspections to monitor the health of all critical measurements, including the millimeter cloud radar, the lidar, microwave radiometers and up- and down-viewing radiometers.

\section{Relation to Other Programs}

ISDAC will be coordinated with experiments to be conducted as part of three International Polar Year activities: International Arctic Systems for Observing the Atmosphere (http://www.ipy.org/development/eoi/proposal-details.php?id=196) the Hydrological Impact of Arctic 
Aerosols (http://www.ipy.org/development/eoi/proposal-details.php?id=140), and POLar study using Aircraft, Remote sensing, surface measurements and modeling of Climate, chemistry, Aerosols and Transport (POLARCAT) (http://www.ipy.org/development/eoi /proposal-details.php?id=32). There is also a proposal for a surface energy budget IOP for 2008, NSA sea surface temperature, which will include daily measurements of water equivalent precipitation, snow depth, snow optical properties, and temperature gradients through the snow and upper soil layer.

NOAA is conducting an airborne experiment, Aerosol, Radiation, and Cloud Processes affecting Arctic Climate (ARCPAC), out of Fairbanks in late March and April 2008. The questions it will address are very similar to those addressed by ISDAC: What are the chemical, optical, and microphysical characteristics of aerosols in the Arctic in springtime? What are the source types (industrial, urban, biomass/biofuel, dust, sea-salt) of the aerosol components, and the absorbing components in particular? What are the microphysical and optical characteristics of optically thin clouds in the lower Arctic troposphere in springtime, and do pollution particles affect these cloud properties? What are the concentration of particles that serve as ice nuclei (IN) in background and polluted air? Is soot present in particles that serve as IN and CCN? What halogen chemistry is occurring during Arctic spring? To address these questions, NOAA will fly its WP-3D aircraft from Fairbanks to Barrow with many of the same type of instruments being deployed for ISDAC. The leader of ARCPAC is Chuck Brock. Further information about ARCPAC is available at http://www.esrl.noaa.gov/csd/ARCPAC/. Since both ISDAC and ARCPAC will be based at Fairbanks, flights can be coordinated to provide improved sampling.

NASA is also conducting an airborne polar experiment during the same period: Arctic Research of the Composition of the Troposphere from Aircraft and Satellites (ARCTAS). ARCTAS has four major scientific themes: 1. Long range transport of pollution to the Arctic including arctic haze, tropospheric ozone, and persistent pollutants such as mercury; 2. Boreal forest fires and their implications for atmospheric composition and climate; 3 . Aerosol radiative forcing from arctic haze, boreal fires, surfacedeposited black carbon, and other perturbations; 4. Chemical processes with focus on ozone, aerosols, mercury, and halogens. ARCTAS will have two deployments, one in April 2008, the other in July. For at least part of April the DC-8 will deploy out of Fairbanks and fly over Barrow. Although as of September 2007 the payload is not yet selected, it is expected to include most of the same aerosol instrumentation and some of the same cloud probes as ISDAC. Further information can be found at http://www.espo.nasa.gov/arctas/.

Matthew Sturm of the U.S. Army Cold Regions Research and Engineering Laboratory and Glenn Liston of Colorado State University has an NSF funded project to augment the existing meteorological and snow measuring instrumentation at the NSA ACRF site with solid-state snow pillows, heated plate precipitation sensors, snow fences, and eddy correlation towers for computation of sublimation. These data will provide critical surface boundary layer data for modeling studies.

\section{Acronyms}

$\begin{array}{ll}\text { ACRF } & \text { ARM Climate Research Facility } \\ \text { AERI } & \text { Atmospheric Emitted Radiance Interferometer } \\ \text { ARM } & \text { Atmospheric Radiation Measurement } \\ \text { ASD } & \text { Analytical Spectral Devices } \\ \text { ASP } & \text { Atmospheric Science Program } \\ \text { BBHRP } & \text { BroadBand Radiative Heating Rate Profile }\end{array}$


CAPS Cloud Aerosol and Precipitation Spectrometer

CAS Cloud and Aerosol Spectrometer

CCN Cloud Condensation Nuclei

CDP Cloud Droplet Probe

CFDC Continuous Flow Diffusion Chamber

CIP Cloud Imaging Probe

CMDL Climate Monitoring and Diagnostics Laboratory

CPI Cloud Particle Imager

CSI Cloud Spectrometer and Impactor

DMA Differential Mobility Analyzer

DMT Droplet Measurement Technologies

DOE Department of Energy

DRI Desert Research Institute

ECMWF European Center for Medium Range Weather Forecasts

TDMA Tandem Differential Mobility Analyzer

IOP Intensive Operations Period

ISDAC Indirect and Semi-Direct Aerosol Campaign

IWC Ice Water Content

IWP Ice Water Path

LWC Liquid Water Content

LWP Liquid Water Path

MFRSR Multifilter Rotating Shadowband Radiometer

M-PACE Mixed-Phase Arctic Cloud Experiment

NSA North Slope of Alaska

PCASP Passive Cavity Aerosol Spectrometer Probe

PI Principal Investigators

PMS Particle Measurement Systems

PSAP Particle Soot/Absorption Photometer

PSD Particle Size Distribution

RASS Radio Acoustic Sounding System

SHEBA Surface Heat Budget of the Arctic

SPEC Stratton Park Engineering Company, Inc.

SPLAT Single Particle Laser Ablation Time of flight mass spectrometer

SST Sea Surface Temperature

TDL Tunable Diode Laser

TRAC Time Resolved Aerosol Collector

TWP-ICE Tropical Warm Pool International Cloud Experiment 


\section{References Cited}

Ackerman, S, OB Toon, DE Stevens, AJ Heymsfield, V Ramanathan, and EJ Welton. 2000. "Reduction of tropical cloudiness." Science 288:1042-1047.

Barrie, LA. 1986. "Arctic air pollution: An overview of current knowledge." Atmos. Environ. 20:643663.

Baumgardner, D, and A Korolev. 1997. "Airspeed corrections for optical array probe sample volumes." J Atmos. Ocean. Tech. 14:1224-1229.

Beard, KV. 1992. "Ice initiation in warm-base convective clouds: An assessment of microphysical mechanisms." Atmos. Res. 28:125-152.

Borys, R. 1989. "Studies of ice nucleation by Arctic aerosol on AGASP-II." J Atmospheric Chemistry 9:169-185, DOI: 10.1007/BF00052831.

Clothiaux, EE, TP Ackerman, GG Mace, KP Moran, RT Marchand, M Miller, and BE Martner. 2000. "Objective determination of cloud heights and radar reflectivities using a combination of active remote sensors at the ARM CART sites." J Applied Meteorology 39:645-665.

Cober, SG, GA Isaac, AV Korolev, and JW Strapp. 2001. "Assessing cloud-phase conditions." J Appl. Meteor. 40:1967-1983.

Cotton, RJ, and PR Field. 2002. "Ice nucleation characteristics of an isolated wave cloud." $Q J R$ Meteorol. Soc. 128:2417-2437.

Curry, JA, RB Rossow, D Randall, and JL Schramm. 1996. "Overview of Arctic cloud and radiation characteristics." J Climate 9:1731-1764.

Curry, JA, and Coauthors. 2000. "FIRE Arctic Clouds Experiment.” Bull. Amer. Meteor. Soc. 81:5-30.

DeSlover, D, WL Smith, PK Piironen and EW Eloranta. 1999. "A methodology for measuring cirrus cloud visible-to-infrared spectral optical depth ratios.” J Atmos. Ocean. Tech. 16:251-262.

Dong, X, TP Ackerman, EE Clothiaux, P Pilewskie, and Y Han. 1997. "Microphysical and radiative properties of boundary layer stratiform clouds deduced from ground-based measurements." J Geophys. Res. 102(D20):23,829-23,843.

Dusek,U, GP Frank, L Hildebrandt, J Curtius, J Schneider, S Walter, D Chand, F Drewnick, S Hings, D Jung, S Borrmann, and MO Andreae. 2006. "Size matters more than chemistry for cloud-nucleating ability of aerosol particles." Science 312:1375-1378.

Ferek, RJ, PV Hobbs, LF Radke, JA Herring, WT Sturges, and GF Cota. 1995. "Dimethyl sulfide in the Arctic atmosphere." J Geophys. Res. 100:26,093-26,104.

Fridlind, AM, AS Ackerman, G McFarquhar, G Zhang, MR Poellot, PJ DeMott, AJ Prenni, and AJ Heymsfield. 2007. "Ice properties of single-layer stratocumulus during the Mixed-Phase Arctic Cloud Experiment (M-PACE): Part II, Model results.” J Geophys. Res., in press.

Frisch, AS, CW Fairall, and JB Snider. 1995. "Measurements of stratus cloud and drizzle parameters in ASTEX with a Ka-band Doppler radar and microwave radiometer." J Atmos. Sci. 52:2788-2799. 
Garrett, TJ, LF Radke, and PV Hobbs. 2002. "Aerosol effects on cloud emissivity and surface longwave heating in the Arctic." J Atmospheric Sciences 59:769-778.

Garrett, TJ, and C Zhao. 2006. "Increased Arctic cloud longwave emissivity associated with pollution from mid-latitudes.” Nature 440, doi:10.1038 /nature04636.

Garrett, TJ, Zhao, C, Dong, X, Mace, GG, \& Hobbs, PV. 2004. "Effects of varying aerosol regimes on low-level Arctic stratus." Geophys. Res. Lett. 31, doi:10.1029/2004GL019928 (2004).

Gasparini, R, DR Collins, E Andrews, PJ Sheridan, JA Ogren, and JG Hudson. 2006a. "Coupling aerosol size distributions and size-resolved hygroscopicity to predict humidity-dependent optical properties and cloud condensation nuclei spectra." J Geophys. Res. 111, D05S13, doi:10.1029/2005JD006092.

Gasparini, R, R Li, DR Collins, RA Ferrare, and VG Brackett. 2006b. "Application of aerosol hygroscopicity measured at the Atmospheric Radiation Measurement Program's Southern Great Plains site to examine composition and evolution." J Geophys. Res., 111, D05S12, doi:10.1029/2004JD005448.

Gerber, H, Y Takano, TJ Garrett and PV Hobbs. 2000. "Nephelometer measurements of the asymmetry parameter, volume extinction coefficient, and backscatter ratio in arctic clouds." J Atmo. Sci. 57:30213034.

Ghan, SJ, and DR Collins. 2004. "Use of in situ data to test a Raman lidar-based cloud condensation nuclei remote sensing method." J Atmos. \& Ocean. Technol. 21:387-394.

Ghan, SJ, TA Rissman, R Elleman, RA Ferrare, D Turner, C Flynn, J Wang, J Ogren, J Hudson, HH Jonsson, T VanReken, RC Flagan, and JH Seinfeld. 2006. "Use of in situ cloud condensation nuclei, extinction, and aerosol size distribution measurements to test a method for retrieving cloud condensation nuclei profiles from surface measurements." J Geophys. Res. 111, D05S10, doi:10.1029/2004JD005752.

Gultepe, I, and G Isaac. 1996. "The relationship between cloud droplet and aerosol number concentrations for climate models.” Int. J Climatol. 16:941- 946.

Gultepe, I, G Isaac, D Hudak, R Nissen and JW Strapp. 2000. "Dynamical and microphysical characteristics of Arctic clouds during BASE." J Climate 13:1225-1254.

Hallett, J, R Purcell, M Roberts, G Vidaurre,and D Wermers. 2005. "Measurement for Characterization of Mixed Phase Clouds." Proceedings of 43rd American Institute of Aeronautics and Astronautics Aerospace Science Meeting, 10 - 13 January 2005, Reno, NV

Hansen, ADA, T J Conway, L P Strele, B A Bodhaine, K W Thoning, P Tans and T Novakov. 1989. "Correlations among combustion effluent species at Barrow, Alaska: Aerosol black carbon, carbon dioxide, and methane." J Atmos. Chem. 9:283-299

Hansen, ADA, AV Polissar, and RC Schnell. 1997a. "Airborne aerosol and black carbon measurements over the East Siberian sea, spring 1992." Atmos. Res., 44:153- 165.

Hansen, JE, M Sato, and R Ruedy. 1997b. "Radiative forcing and climate response." J Geophys. Res. 102:6831-6864. 
Hara, K, S Yamagata, T Yamanouchi, K Sato, A Herber, Y Iwasaka, M Nagatani, and H Nakata. 2003. "Mixing states of individual aerosol particles in spring Arctic troposphere during ASTAR 2000 campaign.” J Geophys. Res. 108(D7):AAC2-1-12.

Hegg, DA, RJ Ferek, and PV Hobbs. 1995. "Cloud condensation nuclei over the Arctic Ocean in early spring." J Appl. Meteorol. 34:251-260.

Hegg, DA, PV Hobbs, S Gasso, JD Nance, and AL Rangno. 1996. "Aerosol measurements in the Arctic relevant to direct and indirect radiative forcing." J Geophys. Res. 101:23,349-23,363.

Hobbs, PV, and AL Rangno. 1998. "Microstructures of low and middle-level clouds over the Beaufort Sea.” QJ R Meteorol. Soc. 124:2035-2071.

Ivanova, D, DL Mitchell, WP Arnott, and M Poellot. 2001. “A GCM parameterization for bimodal size spectra and ice mass removal rates in mid-latitude cirrus clouds." Atmos. Res. 59-60:89-113.

Klein, S, A Fridlind, R McCoy, G McFarquhar, S Menon, H Morrison, D Vernon, S Xie, JJ Yio and M Zhang. 2006. "ARM Cloud Parameterization and Modeling Working Group-GCSS Polar Cloud Working Group Model intercomparison." Available from http://science.arm.gov $/ \mathrm{wg} / \mathrm{cpm} / \mathrm{scm} / \mathrm{scmic} 5$.

Koren, I, YJ Kaufman, LA Remer, and JV Martins. 2004. "Measurement of the effect of Amazon smoke on inhibition of cloud formation." Science 303:1342-1345.

Korolev, AV, GA Isaac, SG Cober, JW Strapp, and J Hallett. 2003. "Microphysical characterization of mixed phase clouds." QJR Meteorol. Soc. 129:39-65.

Korolev, AV, GA Isaac, and J Hallett. 1999. "Ice particle habits in Arctic clouds." Geophys. Res. Lett. 26:1299-1302.

Laskin, A, MJ Iedema, and JP Cowin. 2003. "Time-resolved aerosol collector for CCSEM/EDX singleparticle analysis." Aer. Sci. Technol. 37:246-260.

Lawson, R, BA Baker, CG Schmitt, and TL Jensen. 2001. "An overview of microphysical properties of Arctic clouds observed in May and July 1998 during FIRE ACE.” J Geophys. Res. 106:14989-15014.

Lawson, RP, B Baker, B Pilson and Qixu Mo. 2006. "In situ observations of the microphysical properties of wave, cirrus and anvil clouds. Part 2: Cirrus clouds. In press." J Atmos. Sci.

Leaitch, WR, RM Hoff, S Melnichuk, and AW Hogan. 1984. "Some physical and chemical properties of the Arctic winter aerosol in northeastern Canada." J Climate Appl. Meteor. 23:916-928.

Leck, C, and EK Bigg. 2005. "Biogenic particles in the surface microlayer and overlaying atmosphere in the central Arctic Ocean during summer." Tellus, Ser. B. 57:305-316.

Lubin, D and AM Vogelmann. 2006. "A climatologically significant aerosol longwave indirect effect in the Arctic." Nature 439:453--456.

Matrosov, SY. 1999. "Retrievals of vertical profiles of ice cloud microphysics from radar and IR measurements using tuned regressions between reflectivity and cloud parameters." J Geophys. Res. 104:16 741-16 753. 
Matrosov, SY, AV Korolev, and AJ Heymsfield. 2002. "Profiling cloud ice mass and particle characteristic size from Doppler radar measurements." J Atmos. Oceanic Technol. 19:1003-1018.

McFarquhar, GM, G Zhang, MR Poellot, GL Kok, R McCoy, T Tooman, A Fridlind, and AJ Heymsfield. 2007. "Ice properties of single-layer stratocumulus during the Mixed-Phase Arctic Cloud Experiment (MPACE): Part I, Observations.” J Geophys. Res. in press.

Meskhidze, N, A Nenes, WC Conant, and JH Seinfeld. 2005. "Evaluation of a new cloud droplet activation parameterization with in situ data from CRYSTAL-FACE and CSTRIPE." J Geophys. Res. 110, D16202, doi:10.1029/2004JD005703.

Min, Q-L, and LC Harrison. 1996. "Cloud Properties Derived From Surface MFRSR Measurements and Comparison With GOES Results at the ARM SGP Site.” Geophys. Res. Lett. 23:1641.

Min, Q, E Joseph, and M Duan. 2004. "Retrievals of thin cloud optical depth from a multifilter rotating shadowband radiometer.” J Geophys. Res. 109, D02201, doi:10.1029/2003JD003964.

Mitchell, DL, RP d'Entremont and RP Lawson. 2006. "Passive thermal retrievals of ice and liquid water path, effective size and optical depth and their dependence on particle and size distribution shape." $12^{\text {th }}$ Conf. on Atmospheric Radiation, 10-14 July 2006, Madison, Wisc. Paper 12.5

Mitchell, DL, RP d'Entremont, DH DeSlover and WP Arnott. 2003. "Multispectral thermal retrievals of size distribution shape, effective size, ice water path, optical depth and photon tunneling contribution. $12^{\text {th }}$ Conf. on Satellite Meteorology and Oceanography." AMS Annual Meeting, Long Beach, California, 913 Feb. 2003. Paper P4.26.

Mitchell, DL, PJ Rasch, D Ivanova, G McFarquhar and T Nousiainen. 2006. "The impact of controversial small ice crystals on GCM simulations." $12^{\text {th }}$ AMS Conference on Cloud Physics, 10-14 July, Madison, Wisconsin. Paper J2.9.

Nakajima, T, and MD King. 1990. "Determination of the optical thickness and effective particle radius of clouds from reflected solar measurements. Part I: Theory." J Atmos. Sci. 47(15):1878-1893.

Norman, AL, LA Barrie, D Toom-Sauntry, A Sirois, HR Krouse, SM Li, and S Sharma. 1999. "Sources of aerosol sulfate at Alert: Apportionment using stable isotopes." J Geophys. Res. 104:11,619- 11,631.

Peng, Y, U Lohmann, R Leaitch, C Banic, and M Couture. 2002. "The cloud albedo-cloud droplet effective radius relationship for clean and polluted clouds from RACE and FIREACE." J Geophys. Res. 107:10.1029/2000JD000281.

Pilewskie, P, AF H Goetz, DA Beal, RW Bergstrom, and P Mariani. 1998. "Observations of the spectral distribution of solar radiation at the ground during SUCCESS." Geophys. Res. Lett 25(8):1141-1144.

Poellot, M, D Brown, G McFarquhar, G Zhang and AJ Heymsfield. 2006. "A case study of horizontal variability in Arctic cloud microphysical properties. $12^{\text {th }}$ Conf. Cloud Physics." Amer. Meteor. Soc. Available from http://ams.confex.com/ams/pdfpapers/113487.pdf

Prenni, AJ, JY Harrington, M Tjernstr om, PJ DeMott, A Avramov, C N1129 Long, SM Kreidenweis, PQ Olsson, and J Verlinde. 2007. "Can ice-nucleating1130 aerosols affect Arctic seasonal climate?" Bull. Amer. Meteorol. Soc. 88:541-550, doi:1131 10.1175/BAMS-88-4-541. 
Quinn, PK, TL Miller, TS Bates, JA Ogren, E Andrews, and GE Shaw. 2002. "A 3-year record of simultaneously measured aerosol chemical and optical properties at Barrow, Alaska." J Geophys. Res. 107(D11):doi:10.1029/2001JD001248.

Rangno, AL, and PV Hobbs. 2001. "Ice particles in stratiform clouds in the Arctic and possible mechanisms for the production of high ice concentrations." J Geophys. Res. 106(D14):15,065-15,075.

Rogers, DC, PJ DeMott and SM Kreidenweis. 2001. "Airborne measurements of tropospheric icenucleating aerosol particles in the Arctic spring." J Geophys. Res. 106:15,053-15,063.

Rosinski, J, and G Morgan. 1991. "Cloud condensation nuclei as a source of ice-forming nuclei in clouds." J Aerosol Sci. 22:123-133.

Schmid, B, R Ferrare, C Flynn, R Elleman, D Covert, A Strawa, E Welton, D Turner, H Jonsson, J Redemann, J Eilers, K Ricci, AG Hallar, M Clayton, J Michalsky, A Smirnov, B Holben, and J Barnard. 2006. "How well can we measure the vertical profile of aerosol extinction?" J Geophys. Res. 111, doi:10.1029/2005JD005837.

Shaw, GE. 1982. "Atmospheric turbidity in the polar regions." J Appl. Meteorol. 21:1080-1088.

Shaw, GE. 1988. "Chemical air mass systems in Alaska." Atmospheric Environment 22(10):2239-2248.

Shupe, MD, T Uttal, and SY Matrosov. 2005. "Arctic cloud microphysics retrievals from surface-based remote sensors at SHEBA.” J Appl. Meteor. 44:1544-1562.

Shupe, MD, SY Y Matrosov, and T Uttal. 2006. "Arctic Mixed-Phase Cloud Properties Derived from Surface-Based Sensors at SHEBA.” J Atmos. Sci. 63:697-811.

Turner, DD. 2005. "Arctic mixed-phase cloud properties from AERI-lidar observations: Algorithm and results from SHEBA.” J Appl. Meteor. 44:427-444.

Verlinde, J, JV Harrington, GM McFarquhar, VT Yznnuzzi, A Avramov, S Greenberg, N Johnson, MR Poellot, JH Mather, DD Turner, BD Zak, TP Tooman, AJ Prenni, GL Kok, EW Eloranta, MD Ivey, CP Bahrmann, K Sassen, PJ DeMott and AJ Heymsfield. 2007. "The Mixed-Phase Arctic Cloud Experiment (M-PACE).” Bull. Amer. Meteor. Soc. 88:205-221.

Wang, Z, K Sassen, DN Whiteman and BB Demoz. 2004. "Studying altocumulus with ice virga using ground-based active and passive remote sensors." J Appl. Meteorol. 43:449-460.

Welton, EJ, et al.. 2000. "Ground-based lidar measurements of aerosols during ACE-2: Instrument description, results, and comparisons with other ground-based and airborne measurements." Tellus Ser. B 52:635-650.

Welton, EJ, KJ Voss, PK Quinn, PJ Flatau, K Markowicz, JR Campbell, JD Spinhirne, HR Gordon, and JE Johnson. 2002. "Measurements of aerosol vertical profiles and optical properties during INDOEX 1999 using micro-pulse lidars." J Geophys. Res. 107(D19):8019, doi:10.1029/2000JD000038.

Westwater, ER, Y Han, MD Shupe, and SY Matrosov. 2001. "Analysis of integrated cloud liquid and precipitable water vapor retrievals from microwave radiometers during SHEBA." J Geophys. Res. 106:32 019-32030. 
Woodley, WL, G Gordon, TJ Hendereson, B Vonnegut, D Rosenfeld and A Detwiler. 2003. "Aircraftproduced ice particles (APIPs): Additional results and further insights." J Appl. Meteor. 42:640-651.

Wylie, DP, and JG Hudson. 2002. "Effects of long-range transport and clouds on cloud condensation nuclei in the springtime Arctic." J Geophys. Res. 107, 4318, 10.1029/2001JD000759.

Xie, S, S Klein, M Zhang, J Yio, R Cederwall, and R McCoy. 2006. "Developing large-scale forcing data for single-column and cloud-resolving models from the Mixed-Phase Arctic Cloud Experiment." Accepted, J Geophys. Res.

Yum, SS, and JG Hudson. 2001. "Vertical distributions of cloud condensation nuclei spectra over the springtime Arctic Ocean.” J Geophys. Res. 106:15,045-15,052. 